\title{
ANALYSIS OF THE WEB APPLICATION ON BAYES' THEOREM CONSIDERING DATA SCIENCE AND TECHNOLOGICAL ACCEPTANCE MODEL
}

\author{
Dr. Ricardo-Adan SALAS-RUEDA \\ ORCID: 0000-0002-4188-4610 \\ Instituto de Ciencias Aplicadas y Tecnologia \\ Universidad Nacional Autonoma de Mexico \\ Mexico City, MEXICO \\ Dr. Erika-Patricia SALAS-RUEDA \\ ORCID: 0000-0002-9144-6432 \\ Instituto Tecnologico y de Estudios Superiores de Monterrey \\ Mexico City, MEXICO \\ Rodrigo-David SALAS-RUEDA \\ ORCID: 0000-0002-2598-2042 \\ Universidad Autonoma Metropolitana \\ Mexico City, MEXICO
}

Received: 26/11/2018 Accepted: 21/05/2019

\begin{abstract}
This mixed research aims to design and implement the Web Application on Bayes' Theorem (WABT) in the Statistical Instrumentation for Business subject. WABT presents the procedure to calculate the probability of Bayes' Theorem through the simulation of data about the supply of products. Technology Acceptance Model (TAM), machine learning and data science are used to analyze the impact of WABT on the educational process. The results of machine learning $(60 \%, 70 \%$ and $80 \%$ of training) indicate that WABT positively influences the Motivation, Autonomy, Personalized learning and Active role. Data science identifies predictive models of the impact of WABT on the teaching and learning process through the decision tree technique. In addition, WABT is a pleasant, simple, useful and innovative web tool for the educational field. Finally, teachers can use TAM model, data science and machine learning in order to identify the impact of digital tools on the educational process.
\end{abstract}

Keywords: Technology, learning, TAM model, data science, learning machine.

\section{INTRODUCTION}

The planning and organization of school activities in the 21 st century are being modified due to the emergence of the new information and communication technologies (Abbott, 2016; Aparicio, Bacao, \& Oliveira, 2016; Guerrero \& Noguera, 2018). In particular, universities are identifying their strengths, opportunities, weaknesses and threats in order to innovate the educational context through technology (Salas \& Salas, 2018; Tikoria \& Agariya, 2017). The education system must modify the teaching-learning process in order to meet the expectations and demands of the Society, that is, students need to develop their skills and acquire an active role through digital tools (Fernandez, 2017; Marquez \& Mourelle, 2018). Also, technology and learning methods improve knowledge assimilation, autonomy and motivation (Emelyanova \& Voronina, 2017; Salas \& Vazquez, 2017). 
Advances of the internet are causing that educational institutions design, organize and use websites (Alvarez \& Garcia, 2017; Sun, Xie, \& Anderman, 2018). Therefore, Information and Communication Technologies (ICT) are transforming the functions and roles of students and teachers in the educational field (Murphy \& Stewart, 2017; Roberts, 2018; Salas, 2019; Tejada \& Pozos, 2018). For example, teachers need to develop digital competence in order to plan, design and build new teaching-learning environments (Tejada \& Pozos, 2018). The incorporation of technological applications in school activities allows the innovation of teaching-learning methods and processes (Kryukov \& Gorin, 2017; Lawrence, 2018). Even, the universities are identifying, selecting and using new strategies with the purpose of raising the educational quality (Diep, Cocquyt, Zhu, Vanwing, \& Greef, 2017; Fernandez, 2017; Lee, 2010).

Due to the advancement of technology, various models have emerged on the impact, perception and influence of digital tools in the educational context (Kurt \& Tingoy, 2017). In particular, TAM model describes the degree of acceptance about the use of technology in organizations through the beliefs, behaviors and intentions of individuals (Chow, Herold, Choo, \& Chan, 2012; Kurt \& Tingoy, 2017; Liu, Chen, Sun, Wible, \& Kuo, 2010).

The students of the Statistical Instrumentation for Business subject have problems to assimilate the knowledge related to Bayes' theorem. Therefore, this mixed research proposes the construction of WABT in order to improve the teaching-learning process on the Bayes' theorem. Also, TAM model, machine learning and data science allow knowing the impact of this web application in the Statistical Instrumentation for Business subject.

The research questions are:

- What is the impact of WABT in the Statistical Instrumentation for Business subject considering machine learning $(60 \%, 70 \%$ and $80 \%$ of training)?

- How does the use of WABT influence the teaching-learning process considering TAM model?

- What are the perceptions of the students about the incorporation of WABT in the educational process on Bayes' theorem?

- What are the predictive models about the use of WABT in the educational process by means of the decision tree technique (data science)?

\section{TECHNOLOGY ACCEPTANCE MODEL}

New information and communication technologies are changing the organization and realization of activities in the educational field (Baleghi, Ayub, Mahmud, \& Daud, 2017; Salas, 2016). In fact, the use of digital tools is increasing in the classroom in order to achieve the development of skills (Bortnik, Stozhko, Pervukhina, Tchernysheva, \& Belysheva, 2017). According to Doleck, Bazelais and Lemay (2017), there are several models that analyze the intention and perception of individuals about the use of technology in organizations, for example, Theory of Reasoned Action (TRA), Technology Acceptance Model (TAM), Theory of Planned Behavior (TPB) and Unified Theory of Acceptance and Use of Technology (UTAUT).

TAM model allows analyzing the factors that influence the educational process during the use of information systems (Baleghi, Ayub, Mahmud, \& Daud, 2017; Fong, Lee, Chang, Zhang, Ngaia, \& Lim, 2014). In 1986, Davis proposed this model considering mainly the aspects on Perceived Ease of Use (PEU) and Perceived Usefulness (PU) of the technological applications (Baleghi, Ayub, Mahmud, \& Daud, 2017; Chow, Herold, Choo, \& Chan, 2012; Ngai, Poon, \& Chan, 2007).

Perceived Usefulness is related to the effect of technology on user performance and Perceived Ease of Use refers to the use of technology without effort (Baleghi, Ayub, Mahmud, \& Daud, 2017; Teo, Lee, Chai, \& Wong, 2009). In the field of education, Perceived Usefulness is the perception of students about the use of ICT to achieve the development of competencies (Baleghi, Ayub, Mahmud, \& Daud, 2017). In addition, TAM model proposed by Davis includes external variables, attitudes and intentions (Baleghi, Ayub, Mahmud, \& Daud, 2017; Liu, Chen, Sun, Wible, \& Kuo, 2010). 
Several authors (e.g., Baleghi, Ayub, Mahmud, \& Daud, 2017; Chen \& Chengalur, 2015; Doleck, Bazelais, \& Lemay, 2017) have used TAM model to analyze the impact of the tools of information and communication in the teaching-learning process. For example, Baleghi, Ayub, Mahmud and Daud (2017) propose the use of TAM model to analyze the interactivity, technical support, ease of use and usefulness of the Learning Management System (LMS) in the universities.

Also, Doleck, Bazelais and Lemay (2017) propose the use of TAM model to analyze the ease of use (effectiveness and satisfaction) and utility (peer influence and relative advantage) of social networks in the educational context. Finally, TAM model determines the degree of acceptance related to the use of technology in organizations (Cabero, Gallego, Puentes, \& Jimenez, 2018).

\section{METHOD}

The objective of this mixed research is to analyze the impact of WABT on the educational process considering TAM model, data science and machine learning. WABT presents the procedure to calculate the probability of the Bayes' theorem through the simulation of data about the supply of products by companies.

\section{Participants}

This mixed research was done in a Mexican university during the 2018 school year. The participants are 61 students of the Statistical Instrumentation for Business subject (See Table 1).

Table 1. Research participants

\begin{tabular}{ccc}
\hline Bachelor's degree & Number of students & Average age \\
\hline Administration & 9 & 18.66 \\
Commerce & 19 & 18.78 \\
Accountancy & 15 & 18.86 \\
Marketing & 16 & 18.93 \\
Information Technology & 2 & 19.00 \\
\hline
\end{tabular}

\section{Procedure}

The procedure of this study began with the design and construction of WABT with the purpose of facilitating the teaching-learning process on Bayes' Theorem through the simulation of data about the supply of products by companies. Figure 1 shows the elements of this web application.

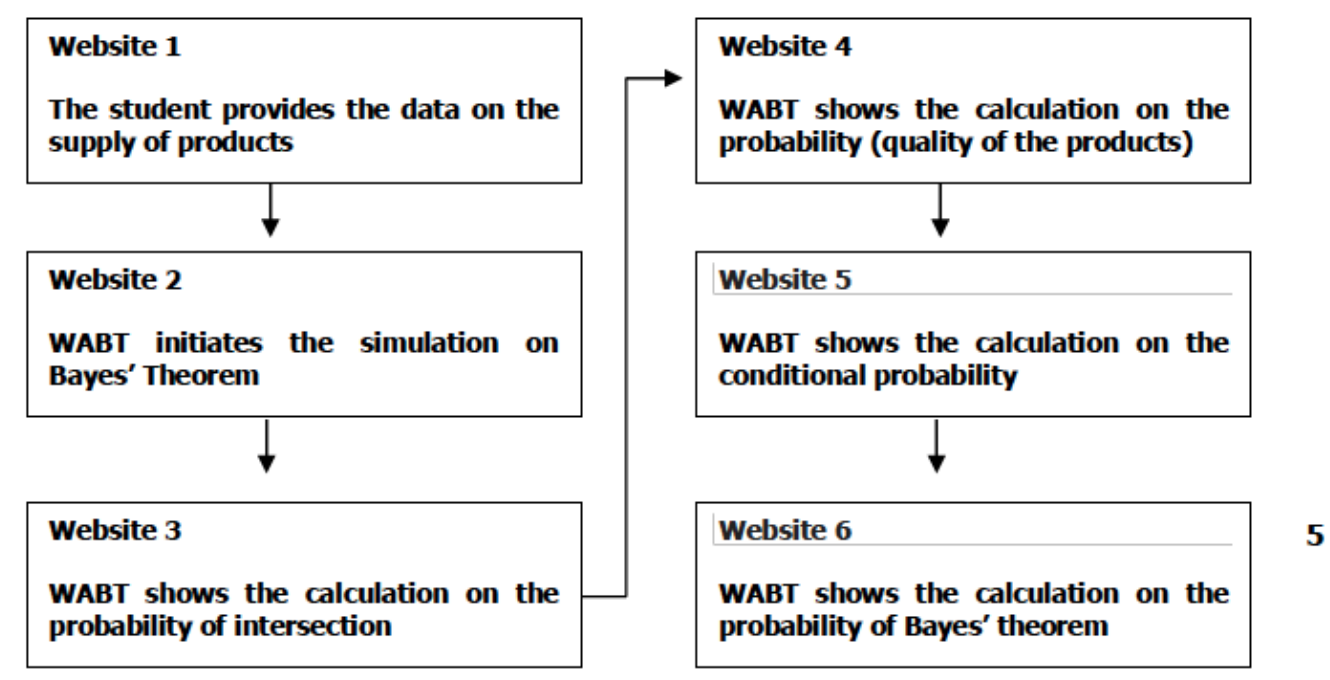

Figure 1. Elements of WABT 
WABT asks for information of the probability on the supply of products: quality (good and poor) and providers (company 1 and company 2). Figure 2 shows the home page on WABT.

\title{
Ceorema de Bayes
}

\author{
Cierta fábrica solicita los productos a la Empresa 1 (e1) y Empresa 2 (e2). \\ La calidad de los productos es Buena(b) o Mala (m). \\ EMPRESA 1 EMPRESA 2 \\ $\mathrm{P}(\mathrm{e} 1) \quad \mathbf{P}(\mathrm{e} 2)$ \\ $\begin{array}{llll}\mathrm{P}(\mathrm{b} / \mathrm{el}) & \mathbf{P}(\mathrm{b} \mid \mathrm{e} 2) & 0.1 & \end{array}$ \\ $\mathrm{P}(\mathrm{m} \mid \mathrm{e} 1) \quad \mathrm{P}(\mathrm{m} \mid \mathrm{e} 2)$
}

Proporciona las probabilidades

\section{Continuar}

Figure 2. Web interface in WABT

To perform the calculation of Bayes' theorem, the probabilities of events (company 1 and company 2) and conditional probabilities (supply of the products) are necessary (See Figure 3).

\section{Ceorema de Bayes}

Cierta fábrica solicita los productos a la Empresa 1 (e1) y Empresa 2 (e2).

La calidad de los productos es Buena(b) o Mala (m).

EMIPRESA 1

EMIPRESA 2

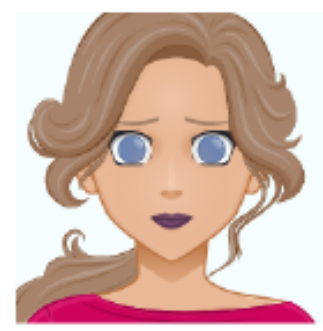

$\mathrm{P}(\mathrm{el})$

0.1

$\mathrm{P}(\mathbf{e})$

$1-0.1=0.9$

$\mathrm{P}(\mathrm{b} \mid \mathrm{el})$

0.1

$\mathrm{P}(\mathrm{b} \mid \mathrm{e} 2)$

0.1

$\mathrm{P}(\mathrm{m} \mid \mathrm{el})$

$1-0.1=0.9$

$\mathbf{P}(\mathbf{m} \mid \mathbf{e} 2)$

$1-0.1=0.9$

Se presenta el cálculo de las probabilidades

\section{Continuar}

Figure 3. Calculation of probabilities in WABT 
Figure 4 shows the calculation on the probabilities of the intersection about the quality (good and poor) and providers (company 1 and company 2 ) in WABT.

\section{Ceorema de Bayes}

\begin{tabular}{|c|c|c|c|}
\hline \multicolumn{4}{|c|}{$\begin{array}{l}\text { Cierta fábrica solicita los productos a la Empresa } 1 \text { (e) } \\
\text { La calidad de los productos es Buena(b) o Mala (m). }\end{array}$} \\
\hline \multicolumn{2}{|c|}{ EMPRESA 1} & \multicolumn{2}{|c|}{ EMPRESA 2} \\
\hline$P(e 1)$ & 0.1 & $P(e 2)$ & $1-0.1=0.9$ \\
\hline $\mathbf{P}(\mathbf{b} \mid \mathbf{e l})$ & 0.1 & $\mathrm{P}(\mathbf{b} \mid \mathbf{e} 2)$ & 0.1 \\
\hline $\mathbf{P}(\mathbf{m} \mid \mathrm{e} l)$ & $1-0.1=0.9$ & $\mathrm{P}(\mathbf{m} \mid \mathrm{e} 2)$ & $1-0.1=0.9$ \\
\hline \multicolumn{4}{|c|}{ INTERSECCIÓN } \\
\hline $\mathrm{P}(\mathrm{el}$ y $\mathrm{b})$ & $0.1 * 0.1=0.01$ & & \\
\hline $\mathrm{P}(\mathrm{el}$ y m) & $0.1 * 0.9=0.09$ & & \\
\hline$P(e 2$ y b $)$ & $0.9 * 0.1=0.09$ & & \\
\hline $\mathrm{P}(\mathrm{e} 2$ y m $)$ & $0.9 * 0.9=0.81$ & & \\
\hline
\end{tabular}

Se presenta el cálculo de las probabilidades sobre la intersección

\section{Continuar}

Figure 4. Calculation on the probability of intersection in WABT

WABT shows the calculation of the probabilities on the good and poor quality of the products (See Figure 5).

\section{Ceorema de Bayes}

Cierta fábrica solicita los productos a la Empresa 1 (e1) y Empresa 2 (e2). La calidad de los productos es Buena(b) o Mala (m).

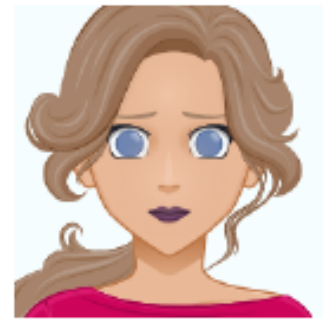

Se presenta el cálculo de las probabilidades sobre el evento
EMPRESA 1

$\begin{array}{cc}\mathrm{P}(\mathrm{el}) & 0.1 \\ \mathrm{P}(\mathrm{b} \mid \mathrm{el}) & 0.1 \\ \mathrm{P}(\mathrm{m} \mid \mathrm{el}) & 1-0.1=0.9\end{array}$

INTERSECCIÓN

P(el y b) $\quad 0.1 * 0.1=0.01$

$\mathrm{P}(\mathrm{el} \mathrm{y} \mathrm{m}) \quad 0.1 * 0.9=0.09$

$\mathbf{P}(e 2$ y b $) \quad 0.9 * 0.1=0.09$

$\mathbf{P}($ e2 y m $) \quad 0.9 * 0.9=0.81$
EMPRESA 2

$\mathrm{P}(\mathrm{e} 2) \quad 1-0.1=0.9$

$\mathrm{P}(\mathrm{b} \mid \mathrm{e} 2) \quad 0.1$

$\mathrm{P}(\mathrm{m} \mid \mathrm{e} 2) \quad 1-0.1=0.9$

EVENTO

P(b) $\quad 0.01+0.09=0.1$

$\mathrm{P}(\mathrm{m}) \quad 0.09+0.81=0.9$

\section{Continuar}

Figure 5. Probability on the good and poor quality of the products in WABT 
To calculate the Bayes' theorem, the probabilities of the intersections and quality of the products (good and poor) are necessary (See Figure 6).

\title{
Ceorema de Bayes
}

\section{Cierta fábrica solicita los productos a la Empresa 1 (e1) y Empresa 2 (e2). La calidad de los productos es Buena(b) o Mala (m).}

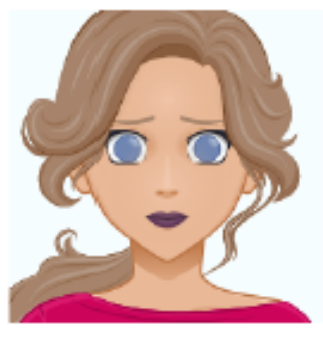

Se presenta el cálculo de las probabilidades condicionales sobre el evento buena
EMPRESA 1

$\begin{array}{cc}P(e l) & 0.1 \\ P(b \mid e l) & 0.1 \\ P(m \mid e l) & 1-0.1=0.9\end{array}$

INTERSECCIÓN

$\mathrm{P}(\mathrm{el}$ y b $) \quad 0.1+0.1=0.01$

$\mathrm{P}(\mathrm{el}$ y m $) \quad 0.1 * 0.9=0.09$

$\mathrm{P}(\mathrm{e} 2$ y b) $\quad 0.9 * 0.1=0.09$

$\mathbf{P}(\mathrm{e} 2 \mathrm{y} \mathrm{m}) \quad 0.9 * 0.9=0.81$

$\mathrm{P}(\mathrm{el} \mid \mathrm{b})$

$0.01 / 0.1=0.1$
EMPRESA 2

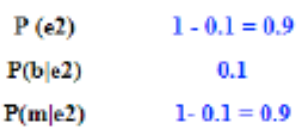

EVENTO

$\mathrm{P}$ (b) $\quad 0.01+0.09=0.1$

$\mathbf{P}(\mathrm{m}) \quad 0.09+0.81=0.9$

$\mathrm{P}(\mathrm{e} 2 \mid \mathrm{b}) \quad 0.09 / 0.1=0.9$

\section{Continuar}

Figure 6. Probability of Bayes' theorem (good quality of the products)

Figure 7 shows the probability of Bayes' theorem on poor quality of the products.

\section{Ceorema de Bayes}

\begin{abstract}
Cierta fábrica solicita los productos a la Empresa 1 (e1) y Empresa 2 (e2). La calidad de los productos es Buena(b) o Mala (m).
\end{abstract}

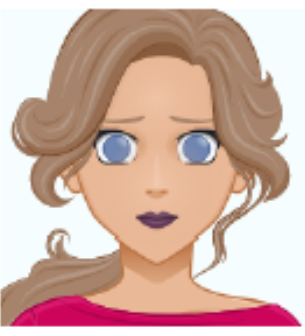

Se presenta el cálculo de las probabilidades condicionales sobre el evento mala
EMIPRESA 1

$\begin{array}{cc}\mathrm{P}(\mathrm{el}) & 0.1 \\ \mathrm{P}(\mathrm{b} \mid \mathrm{el}) & 0.1 \\ \mathrm{P}(\mathrm{m} \mid \mathrm{el}) & 1-0.1=0.9\end{array}$

INTERSECCIÓN

$\begin{array}{ll}\mathrm{P}(\mathrm{e} 1 \mathrm{y} \mathrm{b}) & 0.1 * 0.1=0.01 \\ \mathrm{P}(\mathrm{e} 1 \mathrm{y} \mathrm{m}) & 0.1 * 0.9=0.09 \\ \mathrm{P}(\mathrm{e} 2 \mathrm{y} \mathrm{b}) & 0.9 * 0.1=0.09 \\ \mathrm{P}(\mathrm{e} 2 \mathrm{y} \mathrm{m}) & 0.9 * 0.9=0.81 \\ \mathrm{P}(\mathrm{e} 1 \mid \mathrm{m}) & 0.09 / 0.9=0.1\end{array}$

\section{Continuar}

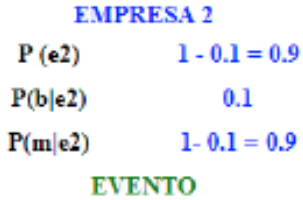

$\mathbf{P}(\mathbf{b}) \quad 0.01+0.09=0.1$

$\mathbf{P}(\mathbf{m}) \quad 0.09+0.81=0.9$

$\mathbf{P}(\mathbf{e} 2 \mathbf{m}) \quad 0.81 / 0.9=0.9$

Figure 7. Probability of Bayes' theorem (poor quality of the products)

The students of the Statistical Instrumentation for Business subject used WABT through the following web address:

http://sistemasusables.com/estadisticaavanzada/sistema4/inicio.html 
This study proposes the development of a model to analyze the use of WABT in the educational process on Bayes' theorem considering TAM model (See Figure 8).

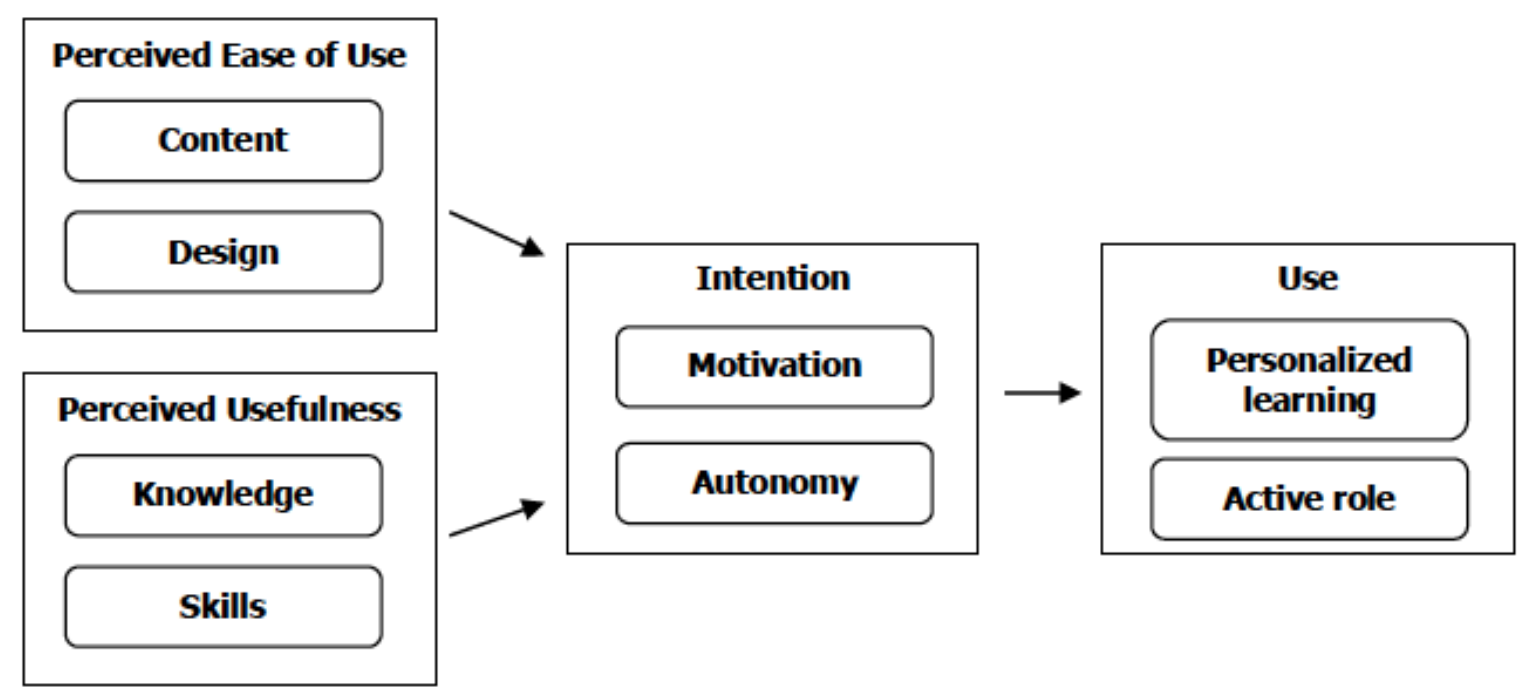

Figure 8. Use of TAM model in this research

Table 2 shows the elements of TAM model used in this research.

Table 2. TAM model

\begin{tabular}{|c|c|c|c|}
\hline Item & TAM model & Dimension & Description \\
\hline \multirow{2}{*}{1} & \multirow{2}{*}{ Perceived Ease of Use } & Content of WABT & $\begin{array}{c}\text { Simulation of data about the supply of products by } \\
\text { companies }\end{array}$ \\
\hline & & Design of WABT & $\begin{array}{c}\text { Aesthetics of the web interface (color, font, images } \\
\text { and distribution of objects) }\end{array}$ \\
\hline \multirow{2}{*}{2} & \multirow{2}{*}{ Perceived Usefulness } & Knowledge & $\begin{array}{c}\text { Assimilation of knowledge about the Bayes' theorem } \\
\text { through WABT }\end{array}$ \\
\hline & & Skills & $\begin{array}{c}\text { Development of mathematical skills on Bayes' } \\
\text { theorem through WABT }\end{array}$ \\
\hline \multirow{2}{*}{3} & \multirow{2}{*}{ Intention } & Motivation & Positive attitude for learning through WABT \\
\hline & & Autonomy & Ability to organize learning through WABT \\
\hline \multirow{2}{*}{4} & \multirow{2}{*}{ Use } & Personalized learning & Management of learning through WABT \\
\hline & & Active role & Participation in learning through WABT \\
\hline
\end{tabular}

The hypotheses of this research related to the aspects of Intention and Perceived ease of use are:

H1: The content of WABT positively influences the motivation of the student during the learning process

H2: The design of WABT positively influences the motivation of the student during the learning process

H3: The content of WABT positively influences the autonomy of the student during the learning process

H4: The design of WABT positively influences the autonomy of the student during the learning process 
Also, the hypotheses about Intention and Perceived Usefulness are:

H5: The assimilation of knowledge through WABT positively influences the motivation of the student during the learning process

H6: The development of skills through WABT positively influences the motivation of the student during the learning process

H7: The assimilation of knowledge through WABT positively influences the autonomy of the student during the learning process

H8: The development of skills through WABT positively influences the autonomy of the student during the learning process

The hypotheses about the Intention and Use of WABT during the teaching-learning process are:

H9: The motivation of the student positively influences personalized learning during the use of WABT

H10: The autonomy of the student positively influences personalized learning during the use of WABT

H11: The motivation of the student positively influences the active role for learning during the use of WABT

H12: The autonomy of the student positively influences the active role for learning during the use of WABT

The tools used in this research are Rapidminer tool and SPSS software. Rapidminer tool allows the construction of predictive models (decision tree technique) and calculation of linear regression by means of machine learning with $60 \%, 70 \%$ and $80 \%$ of training. On the other hand, SPSS software allows calculating Load factor, Cronbach's alpha and Average variance extracted in order to validate the measurement instrument.

Figure 9 shows the use of Rapidminer tool for calculating the linear regression (machine learning). Data Split component allows adjusting the training values $(60 \%, 70 \%$ and $80 \%)$.

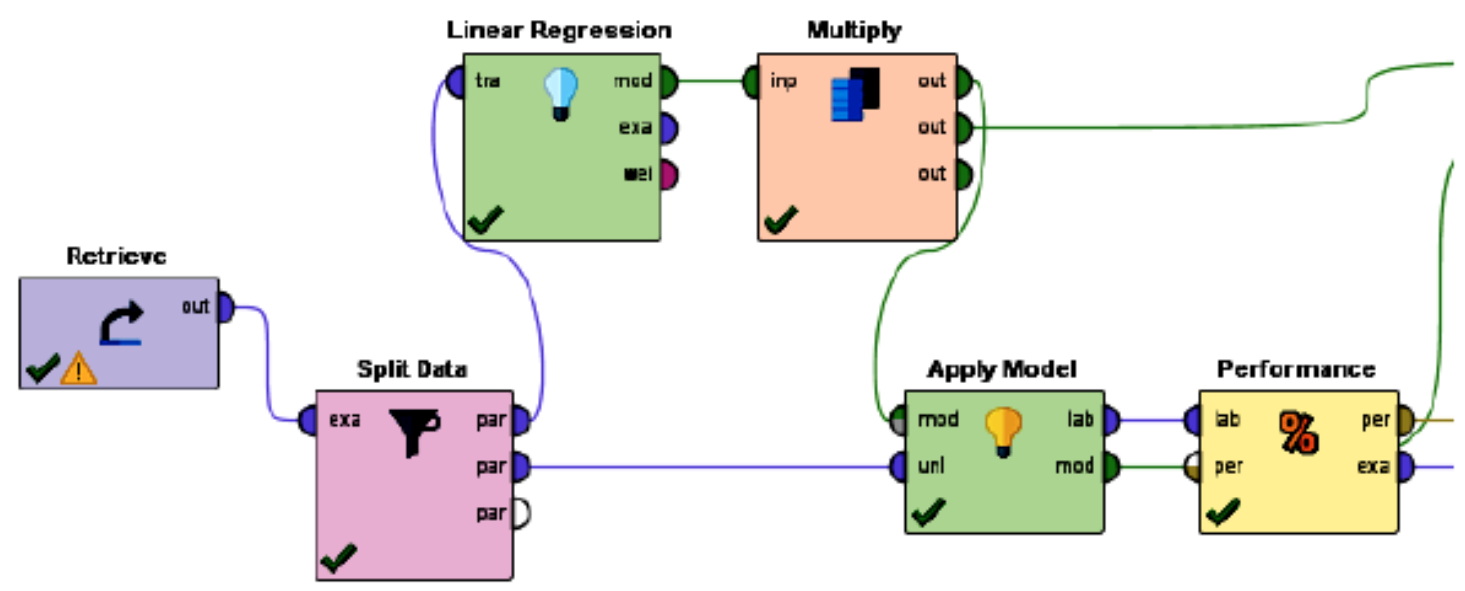

Figure 9. Use of Rapidminer tool for machine learning

The information on the elements of TAM model and the student profile (sex, age and Bachelor's degree) are used for the construction of the following predictive models on the impact of WABT in the motivation and autonomy during the educational process: 
- Predictive model 1 on the content of WABT and motivation of the student during the learning process

- Predictive model 2 on the design of WABT and motivation of the student during the learning process

- Predictive model 3 on the content of WABT and autonomy of the student during the learning process

- Predictive model 4 on the design of WABT and autonomy of the student during the learning process Also, the predictive models of Intention and Perceived Usefulness are:

- Predictive model 5 on the assimilation of knowledge through WABT and motivation of the student during the learning process

- Predictive model 6 on the development of skills through WABT and motivation of the student during the learning process

- Predictive model 7 on the assimilation of knowledge through WABT and autonomy of the student during the learning process

- Predictive model 8 on the development of skills through WABT and autonomy of the student during the learning process

The predictive models of the Intention and Use of WABT are:

- Predictive model 9 on the motivation of the student and personalized learning during the use of WABT

- Predictive model 10 on the autonomy of the student and personalized learning during the use of WABT

- Predictive model 11 on the motivation of the student and active role for learning during the use of WABT

- Predictive model 12 on the autonomy of the student and active role for learning during the use of WABT

Figure 10 shows the use of Rapidminer tool for the construction of predictive models on WABT in the educational process.

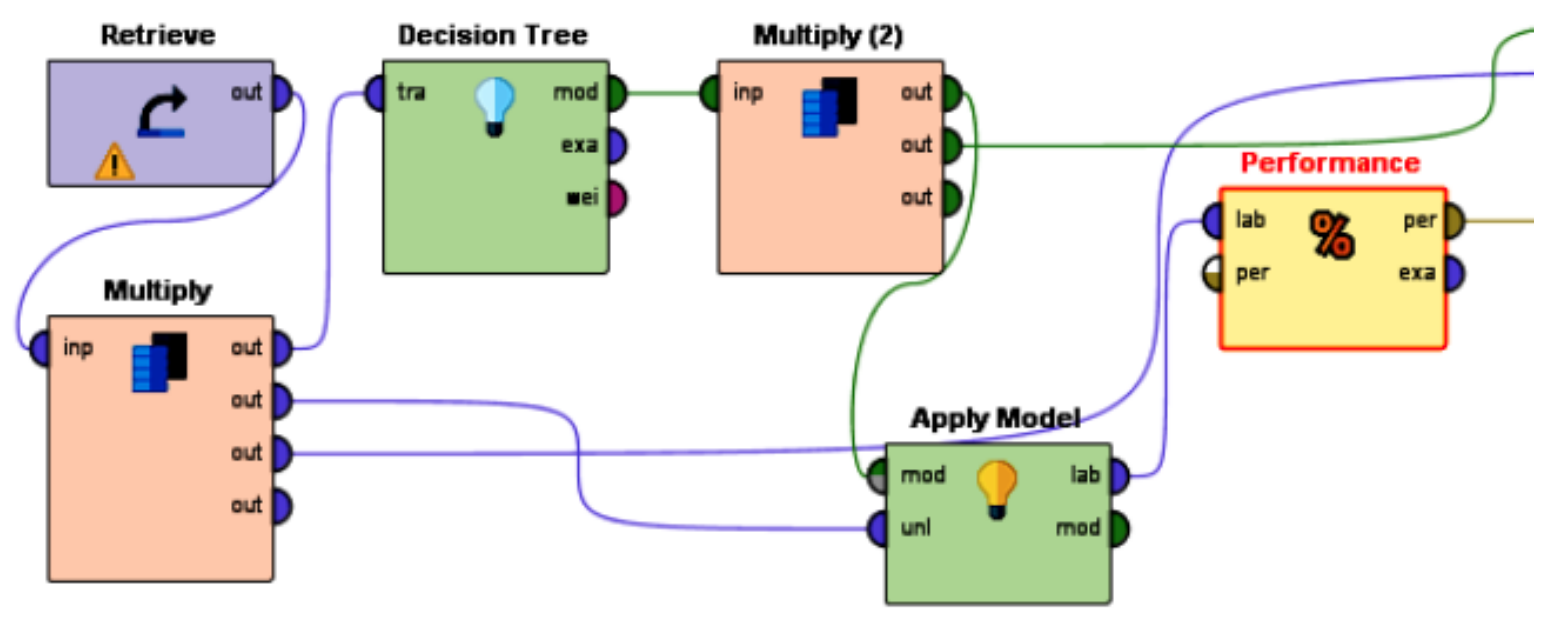

Figure 10. Use of Rapidminer tool for predictive models 


\section{Data Collection}

Table 3 shows the measurement instrument used in this research. The scale used is Very much (1), Some (2), Little (3) and Too little (4).

Table 3. Measurement instrument

\begin{tabular}{|c|c|c|c|c|}
\hline Variable & Dimension & Load factor & $\begin{array}{c}\text { Cronbach's } \\
\text { alpha }\end{array}$ & $\begin{array}{c}\text { Average variance } \\
\text { extracted }\end{array}$ \\
\hline \multirow{2}{*}{ Perceived Ease of Use } & Content & 0.928 & \multirow{2}{*}{0.849} & \multirow{2}{*}{0.711} \\
\hline & Design & 0.749 & & \\
\hline \multirow{2}{*}{ Perceived Usefulness } & Knowledge & 0.913 & \multirow{2}{*}{0.814} & \multirow{2}{*}{0.816} \\
\hline & Skills & 0.894 & & \\
\hline \multirow{2}{*}{ Intention } & Motivation & 0.826 & \multirow{2}{*}{0.805} & \multirow{2}{*}{0.780} \\
\hline & Autonomy & 0.937 & & \\
\hline \multirow{2}{*}{ Use } & Personalized learning & 0.787 & \multirow{2}{*}{0.744} & \multirow{2}{*}{0.740} \\
\hline & Active role & 0.928 & & \\
\hline
\end{tabular}

According to Pock (2007), the values must be higher than 0.60 in Cronbach's Alpha and 0.5 in Load factor to cover the reliability and validity requirements. Table 3 shows that all the variables meet these requirements. Also, Average variance extracted must have a value greater than 0.5 (Pock, 2007). All the values are higher than 0.71 (See Table 3). The variables on the profile of the students are Sex, Age and Career. On the other hand, the qualitative variables are educational process, innovative tool, simulation, benefits, satisfaction and useful.

\section{Analysis of Data}

At the end of the topic on the Bayes' theorem, the measurement instrument is applied. Using SPSS software, the values on Load factor, Cronbach's alpha and Average variance extracted are calculated. Also, Rapidminer tool allows the construction of predictive models (decision tree technique) and calculation of linear regression by means of machine learning with $60 \%, 70 \%$ and $80 \%$ of training.

\section{RESULTS}

The results about the impact of WABT on the educational process are analyzed through machine learning and data science.

\section{Perceived Ease of Use}

The results of machine learning with $60 \%$ of training indicate that hypothesis 1 (0.394), hypothesis 2 (0.540), hypothesis $3(0.672)$ and hypothesis 4 (0.606) are accepted (See Table 4).

Table 4. Machine learning about content and design of WABT ( $60 \%$ of training)

\begin{tabular}{lccc}
\hline \multicolumn{1}{c}{ Hypothesis } & Linear regression & Conclusion & Squared_error \\
\hline H1: Content of WABT $\rightarrow$ Motivation & $y=0.394 x+0.866$ & Accepted: 0.394 & 0.296 \\
H2: Design of WABT $\rightarrow$ Motivation & $y=0.540 x+0.663$ & Accepted: 0.540 & 0.185 \\
H3: Content of WABT $\rightarrow$ Autonomy & $y=0.672 x+0.533$ & Accepted: 0.672 & 0.245 \\
H4: Design of WABT $\rightarrow$ Autonomy & $y=0.606 x+0.601$ & Accepted: 0.606 & 0.177 \\
\hline
\end{tabular}

Hypothesis 1, 2, 3 and 4 of WABT (Content and Design) are accepted through machine learning with 70\% of training (See Table 5). 
Table 5. Machine learning about content and design of WABT (70\% of training)

\begin{tabular}{lccc}
\hline \multicolumn{1}{c}{ Hypothesis } & Linear regression & Conclusion & Squared_error \\
\hline H1: Content of WABT $\rightarrow$ Motivation & $y=0.439 x+0.823$ & Accepted: 0.439 & 0.338 \\
H2: Design of WABT $\rightarrow$ Motivation & $y=0.565 x+0.646$ & Accepted: 0.565 & 0.194 \\
H3: Content of WABT $\rightarrow$ Autonomy & $y=0.710 x+0.470$ & Accepted: 0.710 & 0.321 \\
H4: Design of WABT $\rightarrow$ Autonomy & $y=0.565 x+0.646$ & Accepted: 0.565 & 0.163 \\
\hline
\end{tabular}

The results of machine learning with $80 \%$ of training indicate that hypothesis 1 (0.498), hypothesis 2 (0.610), hypothesis 3 (0.715) and hypothesis 4 (0.584) are accepted (See Table 6).

Table 6. Machine learning about content and design of WABT ( $80 \%$ of training)

\begin{tabular}{lccc}
\hline \multicolumn{1}{c}{ Hypothesis } & Linear regression & Conclusion & Squared_error \\
\hline H1: Content of WABT $\rightarrow$ Motivation & $y=0.498 x+0.736$ & Accepted: 0.498 & 0.483 \\
H2: Design of WABT $\rightarrow$ Motivation & $y=0.610 x+0.578$ & Accepted: 0.610 & 0.267 \\
H3: Content of WABT $\rightarrow$ Autonomy & $y=0.715 x+0.473$ & Accepted: 0.715 & 0.414 \\
H4: Design of WABT $\rightarrow$ Autonomy & $y=0.584 x+0.632$ & Accepted: 0.584 & 0.169 \\
\hline
\end{tabular}

Figure 11 shows the predictive model 1 . If the student considers that the content of WABT facilitates some the teaching-learning process and studies the Bachelor's degree in Administration (Adm) then this web application favors some the motivation of the student during the educational process on Bayes' theorem.

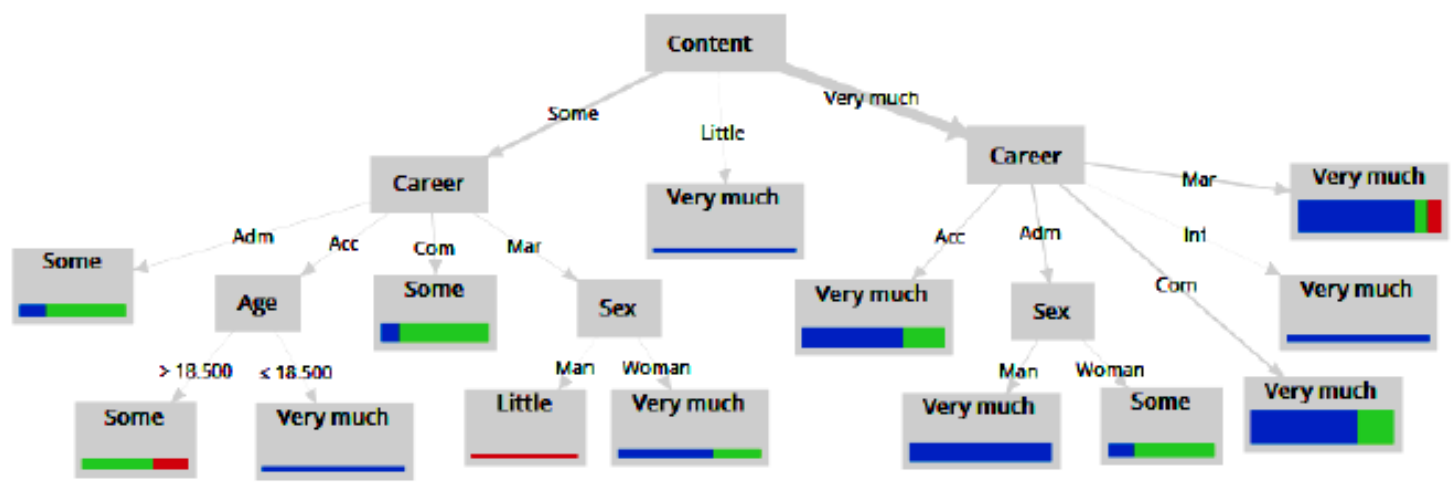

Figure 11. Predictive model 1

The accuracy of the predictive model 1 on the content of WABT and motivation of the student is $80.33 \%$ (See Figure 12).

\begin{tabular}{|c|c|c|c|c|}
\hline & true Very much & true Some & true Lttre & class precision \\
\hline pred. Very much & 35 & 7 & 1 & $81.40 \%$ \\
\hline pred some & 3 & 13 & 1 & $76.47 \%$ \\
\hline pred. Lmlite & 0 & 0 & 1 & $100.00 \%$ \\
\hline dass recall & $92.11 \%$ & $65.00 \%$ & $33.33 \%$ & \\
\hline
\end{tabular}

Figure 12. Accuracy of the predictive model 1 
Figure 13 shows the predictive model 2. If the student considers that the design of WABT facilitates some the teaching-learning process, studies the Bachelor's degree in Marketing (Mar) and is woman then this web application favors very much the motivation of the student during the educational process on Bayes' theorem.

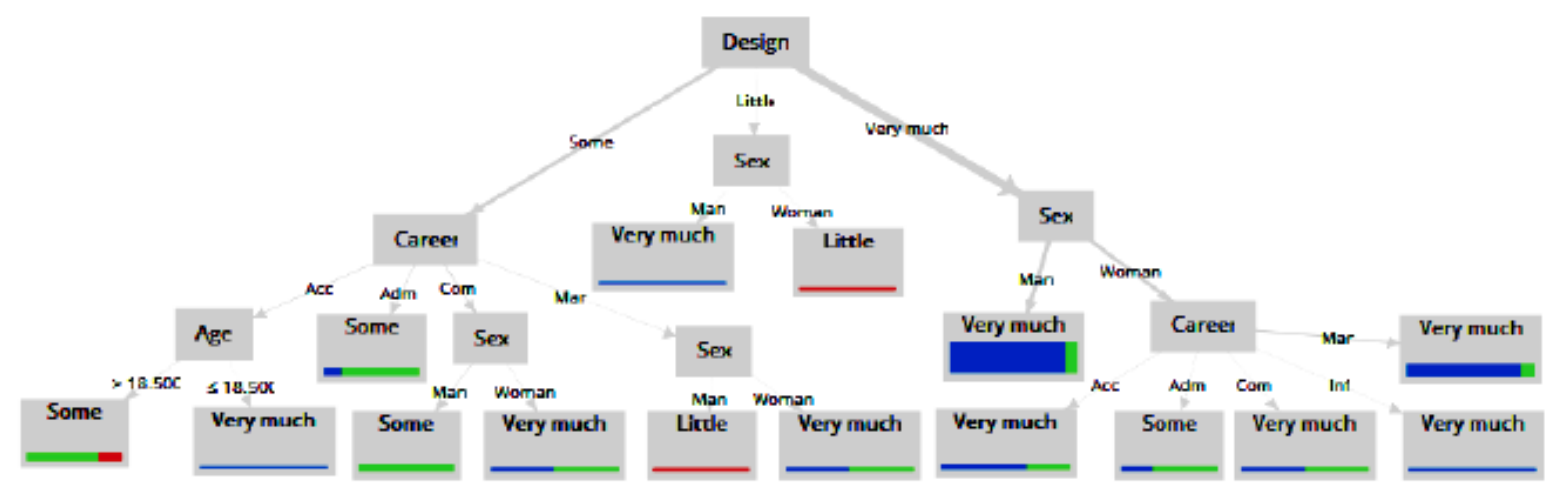

Figure 13. Predictive model 2

The accuracy of the predictive model 2 on the design of WABT and motivation of the student is $83.61 \%$ (See Figure 14).

\begin{tabular}{|c|c|c|c|c|}
\hline & true Very much & true Some & true Little & class precision \\
\hline pred. Very much & 36 & 7 & 0 & $83.72 \%$ \\
\hline pred. Some & 2 & 13 & 1 & $81.25 \%$ \\
\hline pred. uttle & 0 & 0 & 2 & $100.00 \%$ \\
\hline Class recall & $94.74 \%$ & $65.00 \%$ & $66.67 \%$ & \\
\hline
\end{tabular}

Figure 14. Accuracy of the predictive model 2

Figure 15 shows the predictive model 3. If the student considers that the content of WABT facilitates some the teaching-learning process and studies the Bachelor's degree in Marketing (Mar) then this web application favors some the autonomy of the student during the educational process on Bayes' theorem.

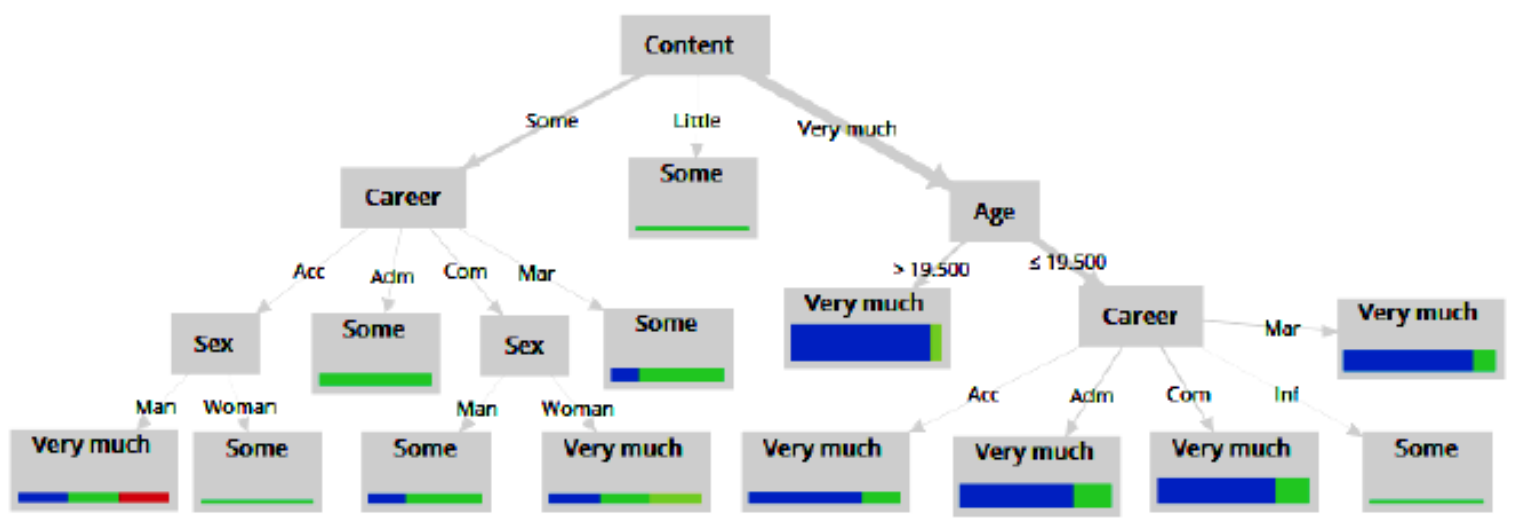

Figure 15. Predictive model 3 
The accuracy of the predictive model 3 on the content of WABT and autonomy of the student is $78.69 \%$ (See Figure 16).

\begin{tabular}{|l|l|l|l|}
\hline accuracy: $78.69 \%$ & true Somb & tub Litte \\
\hline pred. Very much & true Very much & 8 & 2 \\
\hline pred. Some & 36 & 12 & 0 \\
\hline pred. Utule & 2 & 0 & 0 \\
\hline pred. Too little & 0 & 0 & 0 \\
\hline class rbcal & 0 & $60.00 \%$ & $0.00 \%$ \\
\hline
\end{tabular}

Figure 16. Accuracy of the predictive model 3

Figure 17 shows the predictive model 4. If the student considers that the design of WABT facilitates very much the teaching-learning process and is older than 19.5 years then this web application favors very much the autonomy of the student during the educational process on Bayes' theorem.

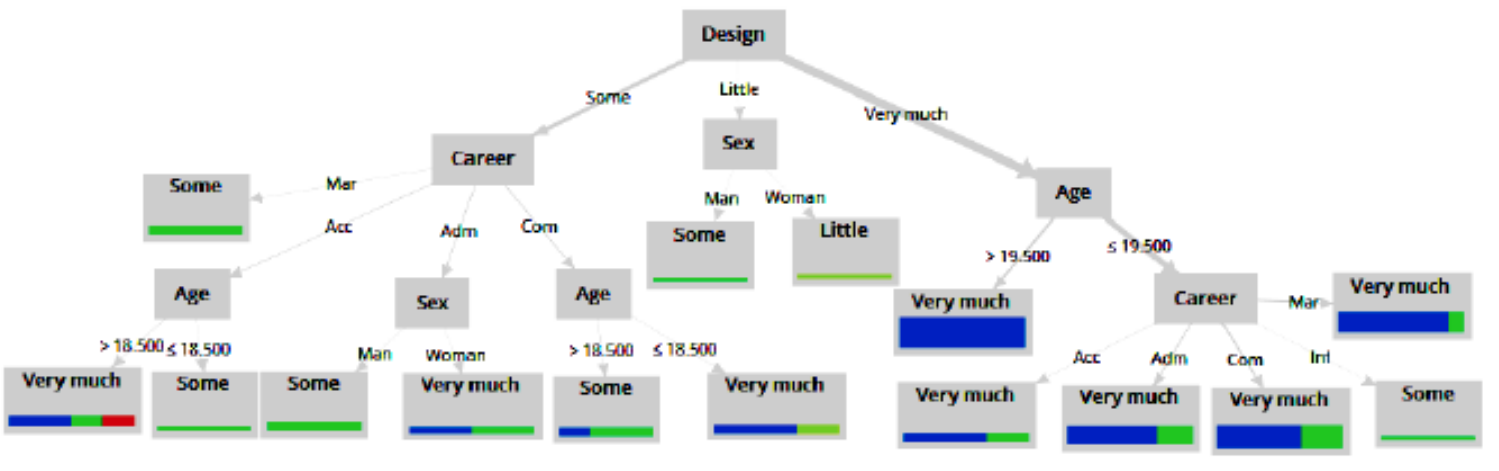

Figure 17. Predictive model 4

Also, if the student considers that the design of WABT facilitates some the teaching-learning process, studies the Bachelor's degree in Administration (Adm) and is woman then this web application favors very much the autonomy of the student during the educational process on Bayes' theorem (See Figure 17). The accuracy of the predictive model on the design of WABT and autonomy of the student is $80.33 \%$ (See Figure 18). 


\begin{tabular}{|c|c|c|c|}
\hline & true very much & true Some & true Litfe \\
\hline pred. Very much & 37 & 9 & 1 \\
\hline pred. Some & 1 & 11 & 0 \\
\hline pred. Litlle & 0 & 0 & 1 \\
\hline pred. Ton little & 0 & 0 & 0 \\
\hline dass recall & $97.37 \%$ & $55.00 \%$ & $50.00 \%$ \\
\hline
\end{tabular}

Figure 18. Accuracy of the predictive model 4

\section{Perceived Usefulness}

The results of machine learning with $60 \%$ of training indicate that hypothesis $5(0.440)$, hypothesis 6 (0.727), hypothesis 7 (0.403) and hypothesis 8 (0.880) are accepted (See Table 7).

Table 7. Machine learning about knowledge and Skills of WABT (60\% of training)

\begin{tabular}{cccc}
\hline Hypothesis & Linear regression & Conclusion & Squared_error \\
\hline $\begin{array}{c}\text { H5:Assimilation of knowledge } \\
\text { through WABT } \rightarrow \text { Motivation }\end{array}$ & $\mathrm{y}=0.440 \mathrm{x}+0.818$ & Accepted: 0.440 & 0.172 \\
$\begin{array}{c}\mathrm{H} 6: \begin{array}{l}\text { Development of skills through } \\
\text { WABT } \rightarrow \text { Motivation }\end{array} \\
\begin{array}{c}\text { H7: Assimilation of knowledge } \\
\text { through WABT } \rightarrow \text { Autonomy }\end{array}\end{array}$ & $\mathrm{y}=0.727 \mathrm{x}+0.454$ & Accepted: 0.727 & 0.253 \\
$\begin{array}{c}\text { H8: Development of skills through } \\
\text { WABT } \rightarrow \text { Autonomy }\end{array}$ & $\mathrm{y}=0.403 \mathrm{x}+0.892$ & Accepted: 0.403 & 0.213 \\
\hline
\end{tabular}

Hypothesis 5, 6,7 and 8 of Assimilation of knowledge and development of skills through WABT are accepted through machine learning with $70 \%$ of training (See Table 8 ).

Table 8. Machine learning about knowledge and Skills of WABT (70\% of training)

\begin{tabular}{cccc}
\hline Hypothesis & Linear regression & Conclusion & Squared_error \\
\hline $\begin{array}{c}\text { H5:Assimilation of knowledge through } \\
\text { WABT } \rightarrow \text { Motivation }\end{array}$ & $y=0.535 x+0.697$ & Accepted: 0.535 & 0.201 \\
$\begin{array}{c}\text { H6: Development of skills through } \\
\text { WABT } \rightarrow \text { Motivation }\end{array}$ & $y=0.731 x+0.459$ & Accepted: 0.731 & 0.300 \\
$\begin{array}{c}\text { H7: Assimilation of knowledge through } \\
\text { WABT } \rightarrow \text { Autonomy } \\
\text { H8: Development of skills through } \\
\text { WABT } \rightarrow \text { Autonomy }\end{array}$ & $y=0.425 x+0.841$ & Accepted: 0.425 & 0.231 \\
& $y=0.889 x+0.257$ & Accepted: 0.889 & 0.371 \\
\hline
\end{tabular}

The results of machine learning with $80 \%$ of training indicate that hypothesis 5 (0.537), hypothesis 6 (0.706), hypothesis 7 (0.414) and hypothesis 8 (0.824) are accepted (See Table 9). 
Table 9. Machine learning about knowledge and Skills of WABT ( $80 \%$ of training)

\begin{tabular}{cccc}
\hline Hypothesis & Linear regression & Conclusion & Squared_error \\
\hline $\begin{array}{c}\text { H5:Assimilation of knowledge through } \\
\text { WABT } \rightarrow \text { Motivation }\end{array}$ & $y=0.537 x+0.674$ & Accepted: 0.537 & 0.230 \\
$\begin{array}{c}\text { H6: Development of skills through } \\
\text { WABT } \rightarrow \text { Motivation }\end{array}$ & $y=0.706 x+0.464$ & Accepted: 0.706 & 0.340 \\
$\begin{array}{c}\text { H7: Assimilation of knowledge through } \\
\text { WABT } \rightarrow \text { Autonomy } \\
\text { H8: Development of skills through } \\
\text { WABT } \rightarrow \text { Autonomy }\end{array}$ & $y=0.414 x+0.857$ & Accepted: 0.414 & 0.236 \\
\hline
\end{tabular}

Figure 19 shows the predictive model 5. If the student considers that the assimilation of knowledge through WABT facilitates some the teaching-learning process, studies the Bachelor's degree in Commerce (Com) and is older than 19.5 years then this web application favors very much the motivation of the student during the educational process on Bayes' theorem.

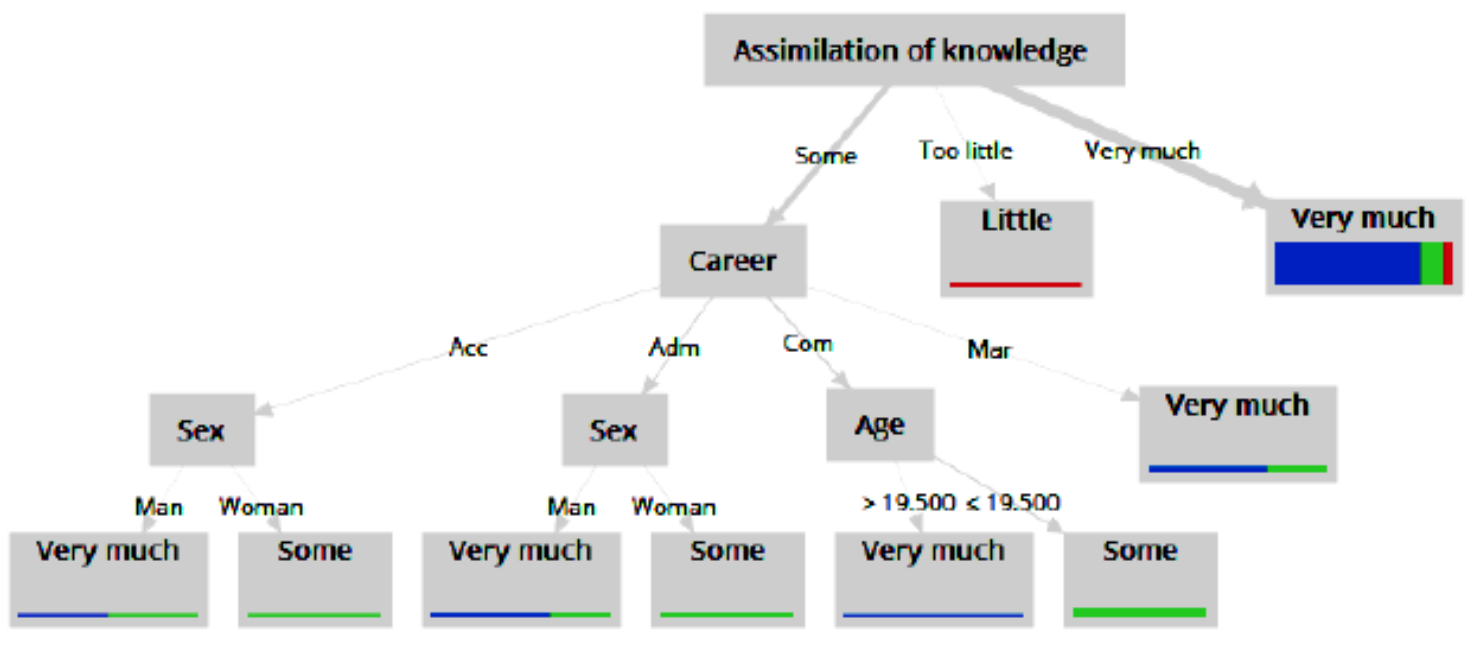

Figure 19. Predictive model 5

The accuracy of the predictive model on the assimilation of knowledge through WABT and motivation of the student is $83.61 \%$ (See Figure 20).

\begin{tabular}{|c|c|c|c|c|}
\hline & true Very much & frue Some & true Little & class precision \\
\hline pred. Very much & 38 & 8 & 2 & $79.17 \%$ \\
\hline pred some & 0 & 12 & 0 & $100.000 \%$ \\
\hline pred. Little & 0 & 0 & 1 & $100.00 \%$ \\
\hline class racall & $100.00 \%$ & $60.00 \%$ & $33.33 \%$ & \\
\hline
\end{tabular}

Figure 20. Accuracy of the predictive model 5

Figure 21 shows the predictive model 6 . If the student considers the development of skills through WABT that facilitates some the teaching-learning process and studies the Bachelor's degree in Administration (Adm) then this web application favors some the motivation of the student during the educational process on Bayes' theorem. 


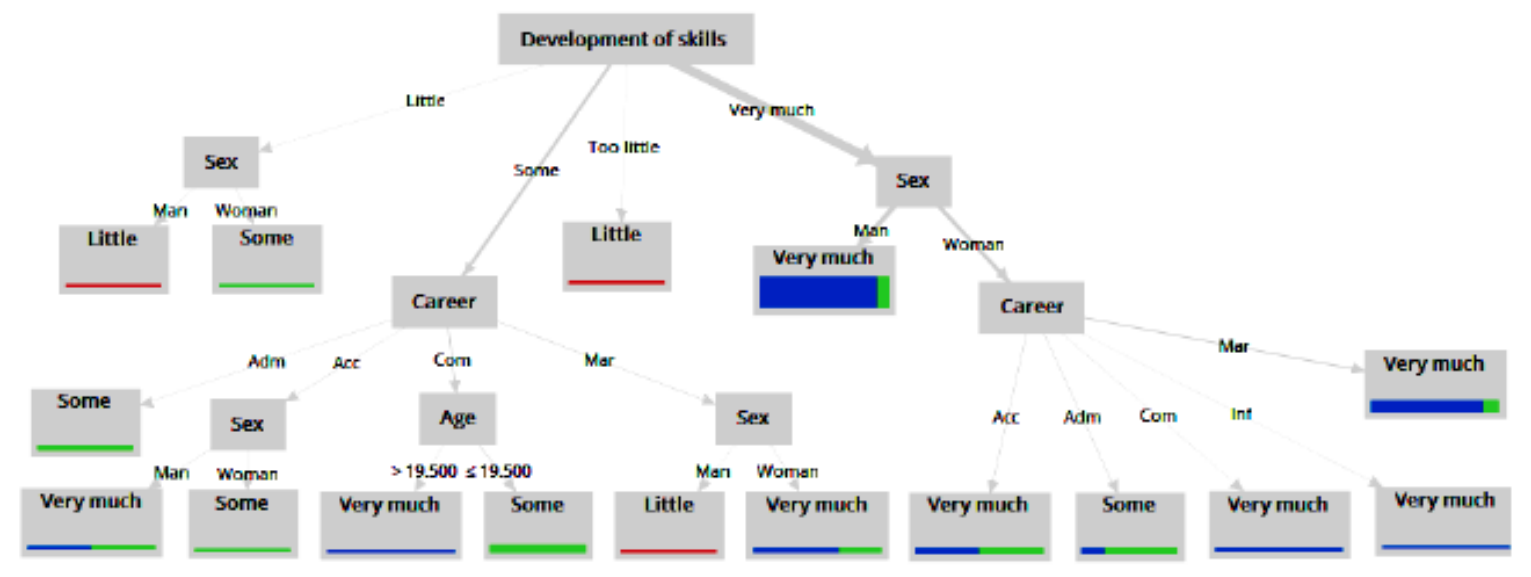

Figure 21. Predictive model 6

The accuracy of the predictive model on the development of skills through WABT and motivation of the student is $86.89 \%$ (See Figure 22).

\begin{tabular}{|c|c|c|c|c|}
\hline & true Very much & true Some & frue Littlle & dass precision \\
\hline pred Very much & 37 & 7 & 0 & $84.09 \%$ \\
\hline pred some & 1 & 13 & 0 & $92.86 \%$ \\
\hline pred. LItlle & 0 & 0 & 3 & $100.00 \%$ \\
\hline dass recall & $97.37 \%$ & $65.00 \%$ & $100.00 \%$ & \\
\hline
\end{tabular}

Figure 22. Accuracy of the predictive model 6

Figure 23 shows the predictive model 7. If the student considers that the assimilation of knowledge through WABT facilitates some the teaching-learning process and studies the Bachelor's degree in Administration (Adm) then this web application favors some the autonomy of the student during the educational process on Bayes' theorem.

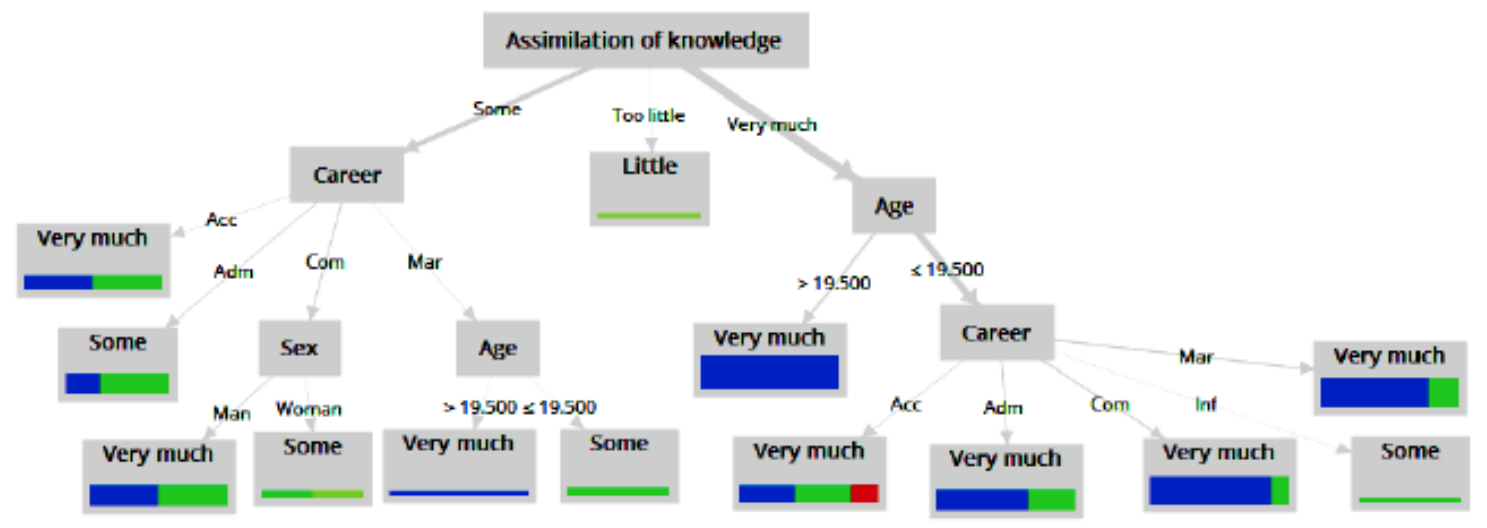

Figure 23. Predictive model 7

The accuracy of the predictive model on the assimilation of knowledge through WABT and autonomy of the student is $73.77 \%$ (See Figure 24). 


\begin{tabular}{|c|c|c|c|c|c|}
\hline & true very much & true Some & true Lttlle & true Too litte & class precision \\
\hline pred. Very muchi & 36 & 12 & 0 & 1 & $73.47 \%$ \\
\hline pred. Some & 2 & 8 & 1 & 0 & $72.73 \%$ \\
\hline pred. Little & 0 & 0 & 1 & 0 & $100.00 \%$ \\
\hline pred. Too little & 0 & 0 & 0 & 0 & $0.00 \%$ \\
\hline Class recall & $94.74 \%$ & $40.00 \%$ & $50.00 \%$ & $0.00 \%$ & \\
\hline
\end{tabular}

Figure 24. Accuracy of the predictive model 7

Figure 25 shows the predictive model 8. If the student considers that the development of skills through WABT facilitates some the teaching-learning process, is older than 19.5 years and studies the Bachelor's degree in Marketing (Mar) then this web application favors very much the autonomy of the student during the educational process on Bayes' theorem.

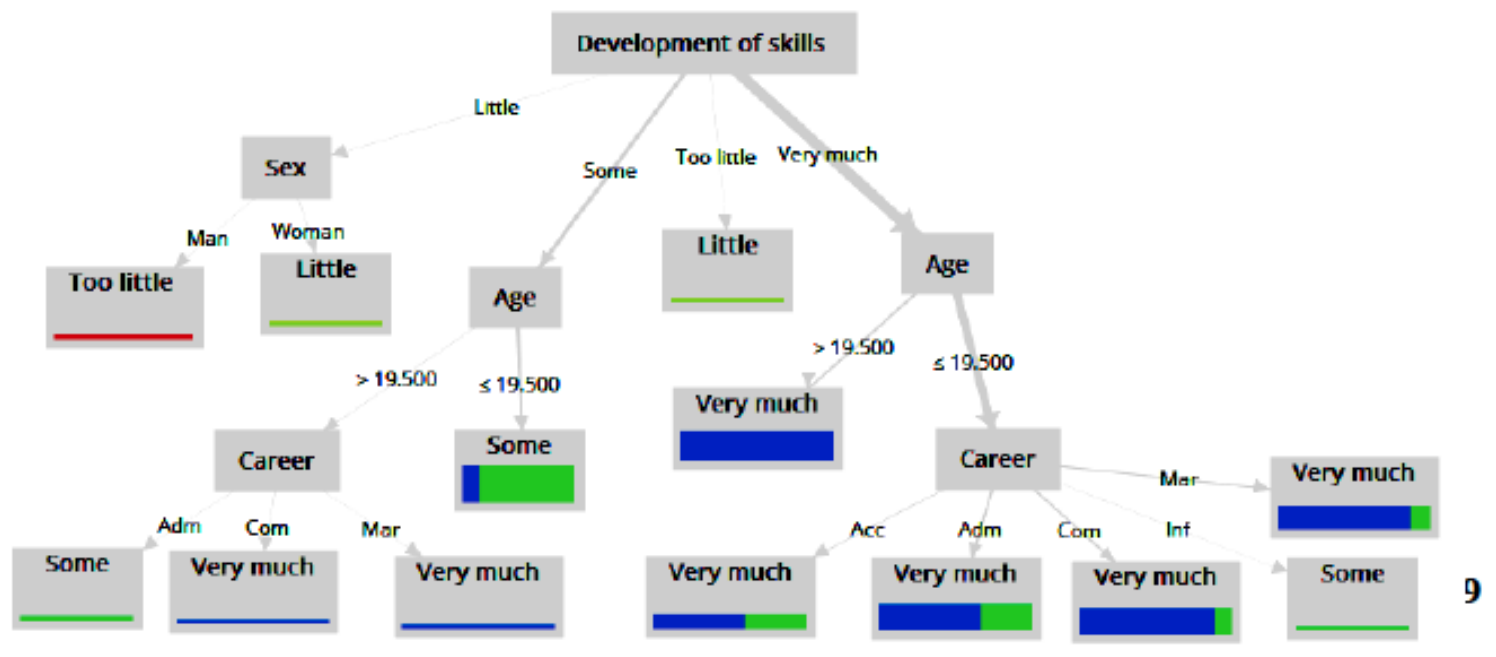

Figure 25. Predictive model 8

The accuracy of the predictive model on the development of skills through WABT and autonomy of the student is $85.25 \%$ (See Figure 26).

\begin{tabular}{|c|c|c|c|c|c|}
\hline & true Very mudr & trus some & true Littig & true Tod little & dass predsion \\
\hline pred. Very much & 36 & 7 & 0 & 0 & $83.72 \%$ \\
\hline pred. Some & 2 & 13 & 0 & 0 & $86.67 \%$ \\
\hline pred. Litte & 0 & 0 & 2 & 0 & $100.00 \%$ \\
\hline pred. Too Iitte & 0 & 0 & 0 & 1 & $100.00 \%$ \\
\hline dass recall & $9474 \%$ & $65.00 \%$ & $100.00 \%$ & $100.00 \%$ & \\
\hline
\end{tabular}

Figure 26. Accuracy of the predictive model 8 


\section{Intention}

The results of machine learning with $60 \%$ of training indicate that hypothesis $9(0.351)$, hypothesis 10 (0.421), hypothesis $11(0.282)$ and hypothesis 12 (0.351) are accepted (See Table 10).

Table 10. Machine learning about Motivation and Autonomy (60\% of training)

\begin{tabular}{cccc}
\hline Hypothesis & Linear regression & Conclusion & Squared_error \\
\hline $\begin{array}{c}\text { H9: Motivation } \rightarrow \text { personalized learning } \\
\text { through WABT }\end{array}$ & $\mathrm{y}=0.351 \mathrm{x}+0.840$ & Accepted: 0.351 & 0.173 \\
$\begin{array}{c}\text { H10: Autonomy } \rightarrow \text { personalized } \\
\text { learning through WABT }\end{array}$ & $\mathrm{y}=0.421 \mathrm{x}+0.731$ & Accepted: 0.421 & 0.136 \\
$\mathrm{H} 11$ Motivation $\rightarrow$ active role through \\
$\begin{array}{c}\text { WABT } \\
\text { H12: Autonomy } \rightarrow \text { active role through } \\
\text { WABT }\end{array}$ & $\mathrm{y}=0.282 \mathrm{x}+0.853$ & Accepted: 0.282 & 0.382 \\
& $\mathrm{y}=0.351 \mathrm{x}+0.803$ & Accepted: 0.351 & 0.340 \\
\hline
\end{tabular}

Hypothesis 9, 10, 11 and 12 of Motivation and Autonomy are accepted through machine learning with 70\% of training (See Table 11).

Table 11. Machine learning about Motivation and Autonomy (70\% of training)

\begin{tabular}{cccc}
\hline Hypothesis & Linear regression & Conclusion & Squared_error \\
\hline $\begin{array}{c}\text { H9: Motivation } \rightarrow \text { personalized learning } \\
\text { through WABT }\end{array}$ & $y=0.340 \mathrm{x}+0.827$ & Accepted: 0.340 & 0.187 \\
$\begin{array}{c}\text { H10: Autonomy } \rightarrow \text { personalized learning } \\
\text { through WABT }\end{array}$ & $\mathrm{y}=0.430 \mathrm{x}+0.702$ & Accepted: 0.430 & 0.149 \\
H11 Motivation $\rightarrow$ active role through \\
$\begin{array}{c}\text { WABT } \\
\text { H12: Autonomy } \rightarrow \text { active role through } \\
\text { WABT }\end{array}$ & $y=0.325 x+0.801$ & Accepted: 0.325 & 0.438 \\
\hline
\end{tabular}

The results of machine learning with $80 \%$ of training indicate that hypothesis 9 (0.395), hypothesis 10 (0.447), hypothesis $11(0.381)$ and hypothesis $12(0.434)$ are accepted (See Table 12).

Table 12. Machine learning about Motivation and Autonomy (80\% of training)

\begin{tabular}{cccc}
\hline Hypothesis & Linear regression & Conclusion & Squared_error \\
\hline $\begin{array}{c}\text { H9: Motivation } \rightarrow \text { personalized learning } \\
\text { through WABT }\end{array}$ & $y=0.395 x+0.757$ & Accepted: 0.395 & 0.229 \\
$\begin{array}{c}\text { H10: Autonom } \rightarrow \text { personalized learning } \\
\text { through WABT }\end{array}$ & $y=0.447 x+0.675$ & Accepted: 0.447 & 0.159 \\
H11 Motivation $\rightarrow$ active role through \\
$\begin{array}{c}\text { WABT } \\
\text { H12: Autonomy } \rightarrow \text { active role through } \\
\text { WABT }\end{array}$ & $y=0.381 x+0.736$ & Accepted: 0.381 & 0.574 \\
& $y=0.434 x+0.694$ & Accepted: 0.434 & 0.534 \\
\hline
\end{tabular}

Figure 27 shows the predictive model 9. If the student considers that the motivation of the student favors very much the teaching-learning process on Bayes' theorem and studies the Bachelor's degree in Accountancy (Acc) then this web application facilitates very much the personalized learning through WABT. 


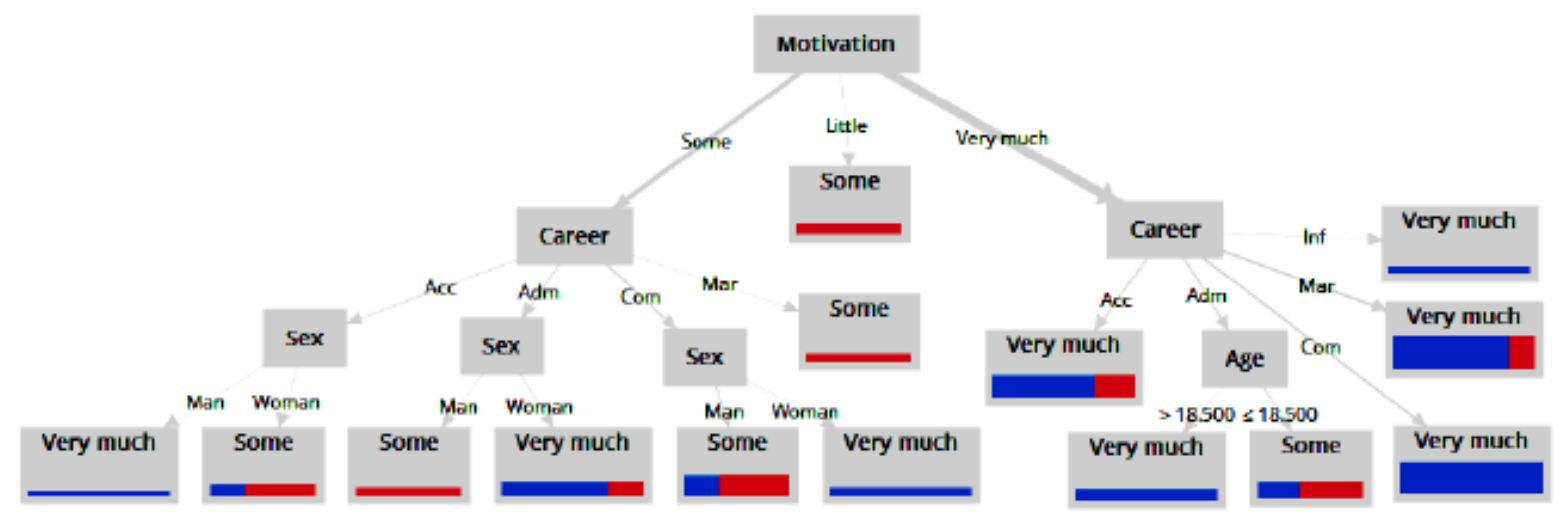

Figure 27. Predictive model 9

If the student considers that the motivation of the student favors very much the teaching-learning process on Bayes' theorem and studies the Bachelor's degree in Marketing (Mar) then this web application facilitates very much the personalized learning through WABT (See Figure 27). The accuracy of the predictive model on the motivation of the student and personalized learning through WABT is $83.61 \%$ (See Figure 28).

\begin{tabular}{|l|l|l|l|}
\hline accuracy. 83.61\% & true Very much & true Some & das5 precision \\
\hline pred. Very much & 35 & 5 & $\mathbf{8 7 . 5 0 \%}$ \\
\hline pred. Some & 5 & 16 & $76.19 \%$ \\
\hline dass recall & $\mathbf{8 7 . 5 0 \%}$ & $\mathbf{7 6 . 1 9 \%}$ & \\
\hline
\end{tabular}

Figure 28. Accuracy of the predictive model 9

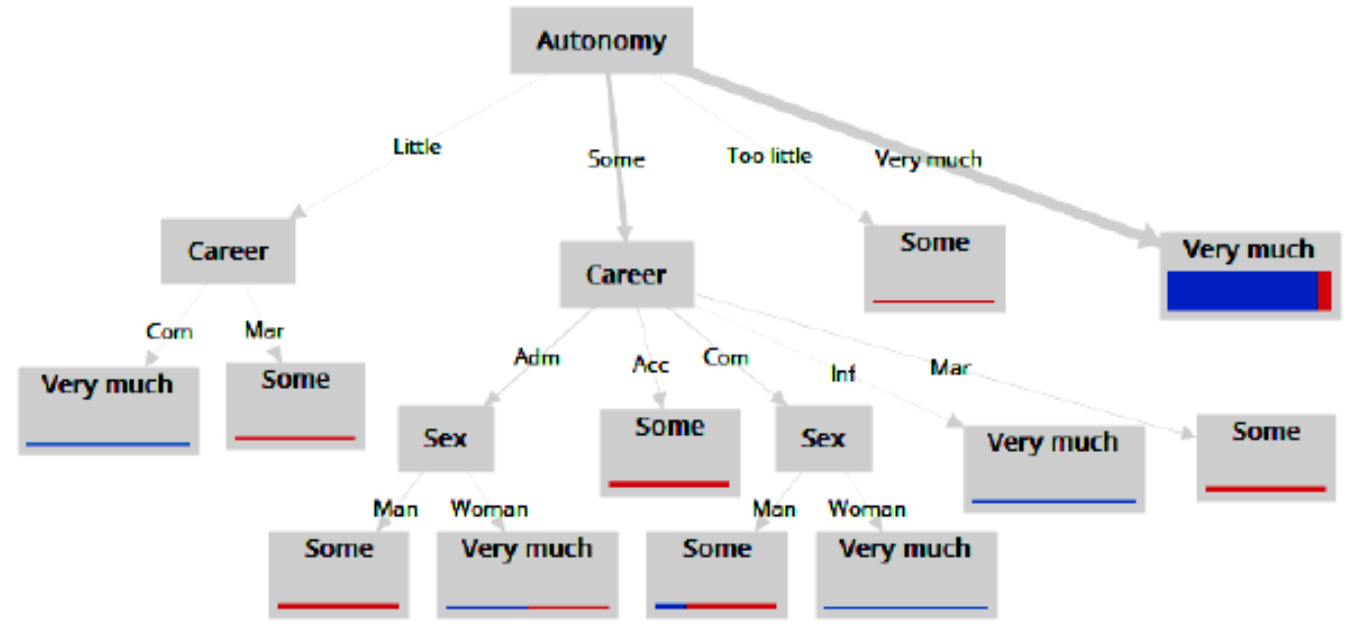

Figure 29. Predictive model 10

The accuracy of the predictive model on the autonomy of the student and personalized learning through WABT is $91.80 \%$ (See Figure 30). 


\begin{tabular}{|c|c|c|c|}
\hline & true Very much & true Some & dass precision \\
\hline pred Very much & 39 & 4 & $90.70 \%$ \\
\hline pred Some & 1 & 17 & $94.44 \%$ \\
\hline dass recall & $97.50 \%$ & $80.95 \%$ & \\
\hline
\end{tabular}

Figure 30. Accuracy of the predictive model 10

Figure 31 shows the predictive model 11. If the student considers that the motivation of the student favors some the teaching-learning process on Bayes' theorem and studies the Bachelor's degree in Administration (Adm) and is man then this web application facilitates some the active role through WABT.

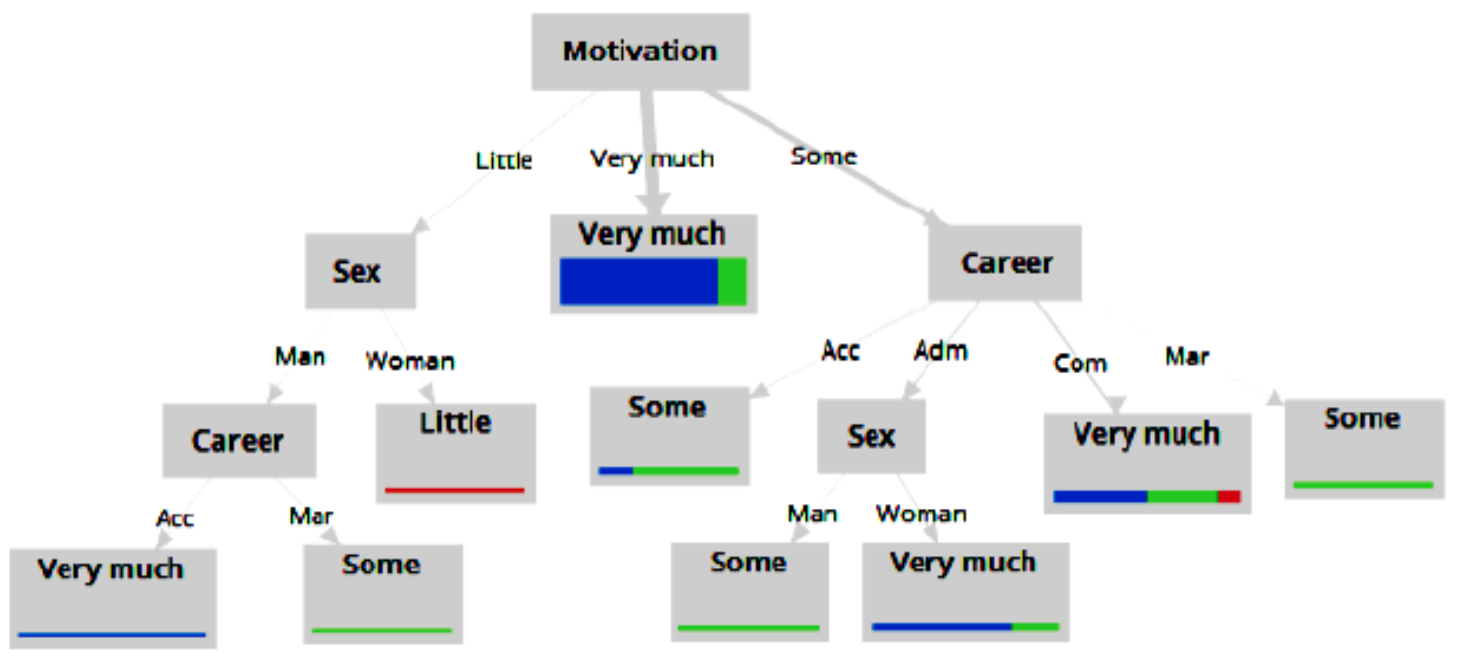

Figure 31. Predictive model 11

The accuracy of the predictive model on the motivation of the student and the active role through WABT is $80.33 \%$ (See Figure 32).

\begin{tabular}{|c|c|c|c|c|}
\hline & true Very much & true Some & true Little & class precision \\
\hline pred. Very much & 40 & 10 & 1 & $78.43 \%$ \\
\hline pred some & 1 & 8 & 0 & $88.89 \%$ \\
\hline pred Lmle & 0 & D & 1 & $100.00 \%$ \\
\hline class recall & $97.56 \%$ & $44.44 \%$ & $50.00 \%$ & \\
\hline
\end{tabular}

Figure 32. Accuracy of the predictive model 11

Figure 33 shows the predictive model 12. If the student considers that the autonomy of the student favors some the teaching-learning process on Bayes' theorem, studies the Bachelor's degree in Commerce (Com) and is man then this web application facilitates very much the active role through WABT. 


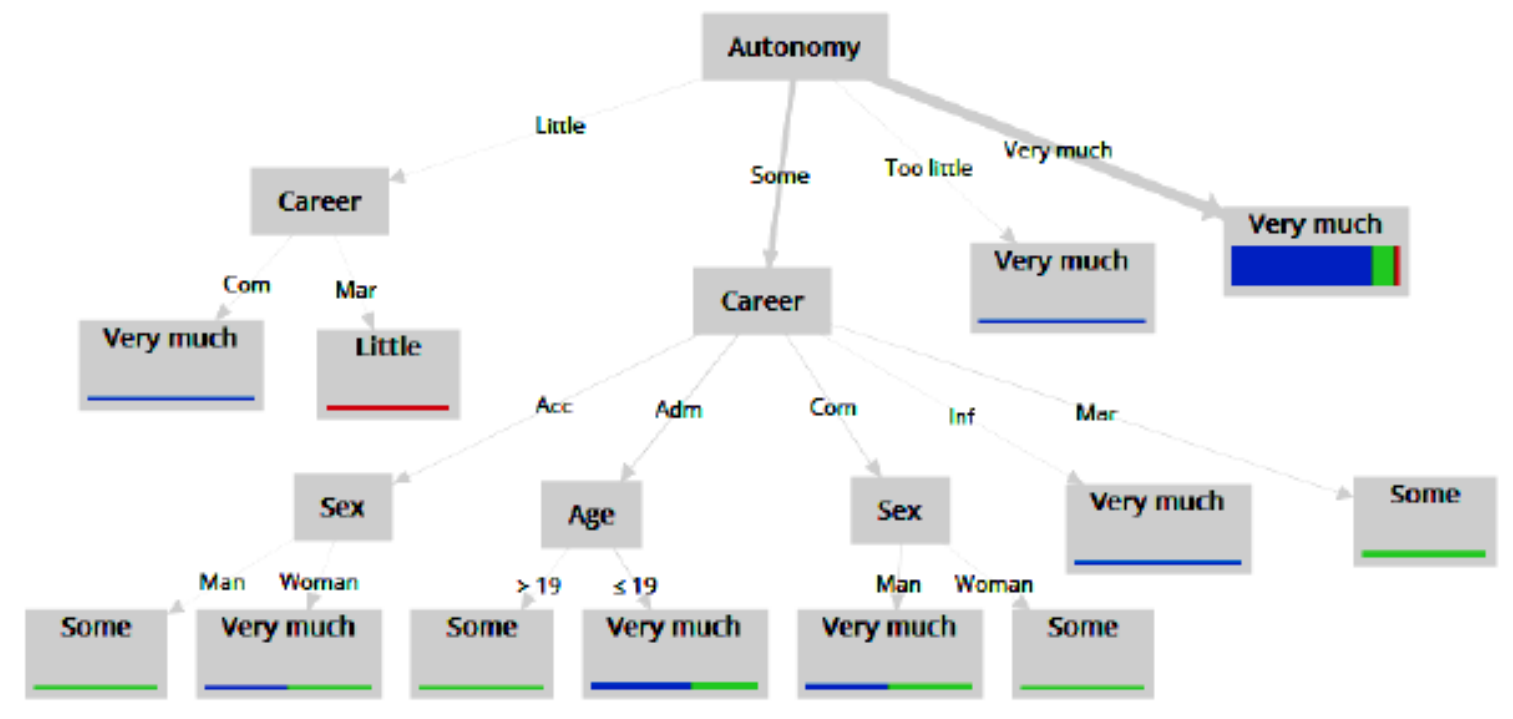

Figure 33. Predictive model 12

The accuracy of the predictive model on the autonomy of the student and the active role through WABT is 81.97\% (See Figure 34).

\begin{tabular}{|l|l|l|l|l|}
\hline accuracy. 81.97\% & true Very much & true Some & true Littie & dass precision \\
\hline pred. Very much & 41 & 10 & 1 & $78.85 \%$ \\
\hline pred. Some & 0 & 8 & 0 & 1 \\
\hline pred. Litte & 0 & 0 & 1 & $100.00 \%$ \\
\hline class recall & $100.00 \%$ & $44.44 \%$ & $50.00 \%$ & $100.00 \%$ \\
\hline
\end{tabular}

Figure 34. Accuracy of the predictive model 12

\section{Perception of the Students}

According to the students of the Statistical instrumentation for Business subject, WABT facilitates the teaching-learning process on Bayes' theorem:

Yes, it helps to practice the probability of Bayes' theorem (Student 10, Female, 20 years old, Marketing).

Yes, it helps to understand the topics (Student 50, Female, 18 years old, Marketing).

WABT is an innovative web tool for the field of statistics:

Yes, it is not like the traditional methods (Student 26, Female, 19 years old, Accounting).

Yes, because it shows the results in detail (Student 61, Female, 20 years old, Administration).

According to the participants, the web interface of WABT is friendly and attractive:

Yes, it is attractive (Student 1, Female, 18 years old, Marketing).

Yes, it is very friendly (Student 23, Male, 19 years old, Commerce).

Likewise, the simulation of WABT facilitates the presentation of the procedure to calculate Bayes' theorem: Yes, because we can analyze several cases (Student 6, Male, 19 years old, Accounting).

Yes, because it shows the procedure and results (Student 40, Male, 18 years old, Accounting). 
One of the benefits of WABT is related to ease of use and fast:

Easy to use and friendly (Student 3, Male, 20 years old, Accounting).

Easy, simple, fast and dynamic (Student 20, Female, 19 years old, Marketing).

Another benefit on WABT is linked to the learning process:

Innovation and personalization of learning (Student 50, Female, 18 years old, Marketing).

Help to review (Student 51, Male, 18 years old, Administration).

The students of the Statistical Instrumentation for Businesses subject are satisfied to use technology during the educational process on the Bayes' theorem:

Yes, I liked using it (Student 11, Female, 18 years old, Commerce).

Yes, because I improved my knowledge (Student 48, Female, 18 years old, Accounting).

Finally, the students point out that WABT is a useful application for the teaching-learning process:

Yes, it helps a lot (Student 23, Male, 19 years old, Commerce).

Yes, it is very helpful (Student 30, Male, 18 years old, Administration).

\section{DISCUSSION}

In the 21st century, teachers are transforming school activities through technological tools (Morales, Escandell, \& Castro, 2018; Salas, Salas, \& Salas, 2019). In particular, this mixed research analyzes the impact of WABT during the educational process on Bayes' theorem. This study shares the ideas of various authors (e.g., Morales, Escandell, \& Castro, 2018; Tikoria \& Agariya, 2017) on the role of digital tools as strategic resources to achieve the objectives of educational institutions. For example, WABT uses simulation to present the probabilities of events, intersection and conditional about the supply of products.

The educational context has changed due to the use of applications in school activities (Tikoria \& Agariya, 2017). In particular, the students of the Bachelor of Administration, Commerce, Accounting, Information Technology and Marketing mention that WABT is an innovative and useful web tool for the field of statistics. The results of machine learning (60\%, $70 \%$ and $80 \%$ of training) indicate that all the hypotheses about the impact of WABT in the educational process are accepted. For example, the content and design of WABT positively influences the motivation and autonomy of the student. In the same way, the assimilation of knowledge and development of skills through WABT positively influences the motivation and autonomy of the student. On the other hand, the motivation and autonomy of the student positively influences the personalized learning and active role during the use of WABT.

Universities are promoting the use of applications in the classroom to develop competences in students (Hajhashemi, Caltabiano, \& Anderson, 2016). Therefore, teachers must use the models on the acceptance of technology in order to analyze the impact of digital tools in the teaching-learning process. TAM model is a reference framework designed to analyze and evaluate the degree of acceptance about the use of technology in organizations (Chen \& Chengalur, 2015; Doleck, Bazelais, \& Lemay, 2017; Liu, Chen, Sun, Wible, \& Kuo, 2010). In this research, this model indicates that WABT favors the personalized learning and active role of students in the Statistical Instrumentation for Business subject. In addition, Perceived Ease of Use and Perceived Usefulness of this web application positively influence the motivation and autonomy during the educational process on Bayes' theorem.

According to Guspatni (2018), the font, images and color allow the construction of pleasant and useful web spaces for the educational field. In particular, WABT presents a pleasant, simple, useful, easy and fast interface for the teaching-learning process. Data science (decision tree technique) allows the identification of predictive models on the use of WABT in the educational process about Bayes' theorem. The accuracy of these predictive models is between $73.77 \%$ and $91.80 \%$. 
Finally, ICTs play a fundamental role during the organization and implementation of school activities (Negre, Marin, \& Perez, 2018). In fact, technological tools facilitate student-centered learning (Bortnik, Stozhko, Pervukhina, Tchernysheva, \& Belysheva, 2017).

\section{CONCLUSION}

Technology is transforming the conditions for teaching and learning. In particular, WABT facilitates the educational process on Bayes' theorem by simulating the probabilities of events, intersection and conditional about the supply of products. TAM model allows identifying the impact of WABT in the educational field, that is, this web application favors the personalized learning and active role of students in the Statistical Instrumentation for Business subject. Also, Perceived Ease of Use (content and design of WABT) and Perceived Usefulness (assimilation of knowledge and development of skills through WABT) positively influence the motivation and autonomy of students.

The limitations of this research are related to the simulation of Bayes' theorem through the presentation of an exercise about the supply of products. In addition, the content of WABT is designed only in the Spanish language. Therefore, future research can build web applications to show various simulations of probability. Artificial intelligence can be used in data simulation to customize the contents of applications. Also, the construction of the content must consider the use of different languages.

Rapidminer tool is an ideal application to perform calculations on machine learning with $60 \%, 70 \%$ and $80 \%$ of training(linear regression) and build predictive models by means of data science (decision tree technique). Technology is fostering the creation of new scenarios for learning and teaching such as WABT. Therefore, teachers must identify, select, analyze and evaluate the impact of digital tools in order to develop competences in students.

\section{BIODATA AND CONTACT ADDRESSES OF AUTHORS}

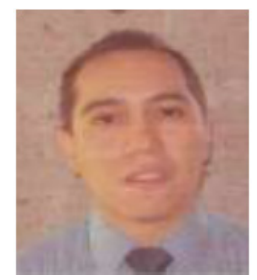

Dr. Ricardo-Adan SALAS-RUEDA, is a full time researcher in the Instituto de Ciencias Aplicadas y Tecnologia, Universidad Nacional Autonoma de Mexico. Dr. Ricardo-Adan gained his Ph.D. in New Technologies Design. His academic interest areas are educative technology, web application design, data science, machine learning and neural networks. He has 22 journal articles published in international indexes, 10 international book chapters and 4 international books.

Ricardo-Adan SALAS-RUEDA

Instituto de Ciencias Aplicadas y Tecnologia, Universidad Nacional Autonoma de Mexico

Address: Circuito Exterior S/N, Ciudad Universitaria, 04510, Mexico City, Mexico.

Phone: +5556228601

E-mail: ricardo.salas@icat.unam.mx

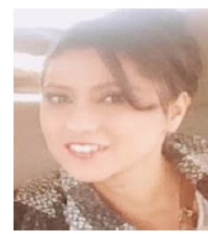

Dr. Erika-Patricia SALAS-RUEDA, has gained her Ph.D. in Humanistic studies at Instituto Tecnologico y de Estudios Superiores de Monterrey, Mexico. Her academic interest areas are educative technology, web application design, data science, pedagogy, ICT, machine learning and neural networks. She has 6 journal articles published in international indexes and 1 international book.

Erika-Patricia SALAS-RUEDA

Instituto Tecnologico y de Estudios Superiores de Monterrey

Address: Maria Auxiliadora 7, Coapa, San Bartolo el Chico, Tlalpan, 14380, Mexico City, Mexico.

Phone: +5514959555

E-mail: serik_patt@hotmail.com 


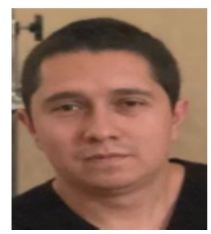

Rodrigo-David SALAS-RUEDA, has gained his Bachelor in Administration at Universidad Autonoma Metropolitana. His academic interest areas are educative technology, web application design, data science, pedagogy, ICT, machine learning and neural networks. He has 7 journal articles published in international indexes and 1 international book.

Rodrigo-David SALAS-RUEDA

Universidad Autonoma Metropolitana

Address: Calz. del Hueso 1100, Coapa, Villa Quietud, Coyoacan, 04960, Mexico City, Mexico

Phone: +5532089477

E-mail: rodrigodavidsalas@hotmail.com

\section{REFERENCES}

Abbott, R. (2016). Embracing Digital Technologies in Classroom Practice: The Impact of Teacher Identity. Australian Educational Computing, 31(2), 1-26.

Alvarez Alvarez, C. \& Garcia, J. I. (2017). The management of schools' websites in Cantabria Spain. Research in Learning Technology, 25(1), 1-12. doi: http://dx.doi.org/10.1080/21567069.2017.1270579

Aparicio, M., Bacao, F., \& Oliveira, T. (2016). Cultural impacts on e-learning systems success. The Internet and Higher Education, 31, 58-70. doi: https://doi.org/10.1016/j.iheduc.2016.06.003

Baleghi Zadeh, S., Ayub, A. F. M., Mahmud, R., \& Daud, S. M. (2017). The influence of system interactivity and technical support on learning management system utilization. Knowledge Management \& E-Learning, 9(1), 50-68.

Bortnik, B., Stozhko, N., Pervukhina, I., Tchernysheva, A., \& Belysheva, G. (2017). Effect of virtual analytical chemistry laboratory on enhancing student research skills and practices. Research in Learning Technology, 25(1), 1-20. doi: http://dx.doi.org/10.25304/rlt.v25.1968

Cabero Almenara, J., Gallego Perez, O., Puentes Puente, A., \& Jimenez Rosa, T. (2018). The Acceptance of Virtual Training Technology and its relationship with teacher training in virtual training. Revista de Educacion Mediatica y TIC, 7(1), 225-241. doi: https://doi.org/10.21071/edmetic.v7i1.10028

Chen, Y. H. \& Chengalur-Smith, I. S. (2015). Factors influencing students' use of a library Web portal: Applying course-integrated information literacy instruction as an intervention. The Internet and Higher Education, 26, 42-55. doi: https://doi.org/10.1016/j.iheduc.2015.04.005

Chow, M., Herold, D. K., Choo, T. M., \& Chan, K. (2012). Extending the technology acceptance model to explore the intention to use Second Life for enhancing healthcare education. Computers \& Education, 59(4), 1136-1144. doi: https://doi.org/10.1016/j.compedu.2012.05.011

Diep, N. A., Cocquyt, C., Zhu, C., Vanwing, T., \& Greef, M. (2017). Effects of core self-evaluation and online interaction quality on adults' learning performance and bonding and bridging social capital. The Internet and Higher Education, 34, 41-55. doi: https://doi.org/10.1016/j.iheduc.2017.05.002

Doleck, T., Bazelais, P., \& Lemay, D. J. (2017). Examining the antecedents of Facebook acceptance via structural equation modeling: A case of CEGEP students. Knowledge Management \& E-Learning, 9(1), 69-89.

Emelyanova, N., \& Voronina, E. (2017). Introducing blended learning in the English language classroom: Students' attitudes and perceptions before and after the course. Knowledge Management \& E-Learning, 9(1), 33-49.

Fernandez Solo, I. (2017). Improving competences: introducing Quality Management in new Education Methodologies. Profesorado, 21 (2), 279-308.

Fong, R. W. T., Lee, J. C. K., Chang, C. Y., Zhang, Z., Ngaia, A. C., \& Lim, C. P. (2014). Digital teaching portfolio in higher education: Examining colleagues' perceptions to inform implementation strategies. The Internet and Higher Education, 20, 60-68. doi: https://doi.org/10.1016/j. iheduc.2013.06.003 
Guerrero Roldan, A. E. \& Noguera, I. (2018). A model for aligning assessment with competences and learning activities in online courses. The Internet and Higher Education, 38, 36-46. doi: https:// doi.org/10.1016/j.iheduc.2018.04.005

Guspatni, A. (2018). Students' activities in, perceptions of and expectations for e-learning: A case in Indonesia. Knowledge Management \& E-Learning, 10(1), 97-112.

Hajhashemi, K., Caltabiano, N., \& Anderson, N. (2016). Students' perceptions and experiences towards the educational value of online videos. Australian Educational Computing, 31(2), 1-17.

Kryukov, V. \& Gorin, A. (2017). Digital technologies as education innovation at universities. Australian Educational Computing, 32(1), 1-16.

Kurt, O. E. \& Tingoy, O. (2017). The acceptance and use of a virtual learning environment in higher education: an empirical study in Turkey, and the UK. International Journal of Educational Technology in Higher Education, 14, 1-15. doi: https://doi.org/10.1186/s41239-017-0064-z

Lawrence, B. (2018). Innovating in the real world: exploring institutional effects on tertiary teacher innovations in New Zealand. Distance Education, 39(1), 54-68. doi: https://doi.org/10.1080/015 87919.2017.1413932

Lee, J. W. (2010). Online support service quality, online learning acceptance, and student satisfaction. The Internet and Higher Education, 13(4), 277-283. doi: https://doi.org/10.1016/j.iheduc.2010.08.002

Liu, I. F., Chen, M. C., Sun, Y. S., Wible, D., \& Kuo, C. H. (2010). Extending the TAM model to explore the factors that affect Intention to Use an Online Learning Community. Computers \& Education, 54(2), 600-610. doi: https://doi.org/10.1016/j.compedu.2009.09.009

Marquez-Ramos, L., \& Mourelle, E. (2018). On the relationship between society and higher education: what path should we take? Distance Education, 39(1), 19-36. doi: https://doi.org/10.1080/01587 919.2018.1436401

Morales Almeida, P., Escandell Bermudez, M. O., \& Castro Sanchez, J. J. (2018). Teacher training in ICT and their thoughts on the integration of ICT in adult centers. Profesorado, 22(1), 541-560.

Murphy, C. A., \& Stewart, J. C. (2017). On campus students taking online courses: Factors associated with unsuccessful course completion. The Internet and Higher Education, 34, 1-9. doi: https://doi. org/10.1016/j.iheduc.2017.03.001

Ngai, E. W., Poon, J. K., \& Chan, Y. H. (2007). Empirical examination of the adoption of WebCT using TAM. Computers \& Education, 48(2), 250-267. doi: https://doi.org/10.1016/j.compedu.2004.11.007

Negre Bennasar, F., Marin Juarros, V., \& Perez Garcias, A. (2018). Content curation as a requirement for 21 st century's teacher training: Analysis of didactic strategies for its acquisition. Profesorado, 22(1), 277-300.

Pock, A. (2007). Strategic Management in Islamic Finance. Germany: Springer.

Roberts, J. (2018). Future and changing roles of staff in distance education: a study to identify training and professional development needs. Distance Education, 39(1), 37-53. doi: https://doi.org/10.1080/ 01587919.2017 .1419818

Salas Rueda, R. A. (2016). The impact of usable system for regression analysis in higher education. International Journal of Educational Technology in Higher Education, 13(1), 1-10. doi: https://doi. org/10.1186/s41239-016-0004-3

Salas Rueda, R. A. (2019). Construction and evaluation of a web application for the educational process on Normal Distribution considering the science of data and machine learning. Research in Learning Technology, 27, 1-24.

Salas Rueda, R. A., Salas Rueda, E. P., \& Salas Rueda, R. D. (2019). Design and use of a web application for the field of statistics considering the assure model and data science. Texto Livre: Linguagem $e$ Tecnologia, 12(1), 1-24. 
Salas Rueda, R. A. \& Salas Silis, J. A. (2018). Logic.ly Simulator. Technological tool to facilitate the teachinglearning process about Mathematics? Revista Dilemas Contemporaneos: Educacion, Politica y Valores, 5(3), 1-25.

Salas Rueda, R. A. \& Vazquez Estupican, J. J. (2017). Innovation in the higher educational process through erpag cloud service. Revista electronica calidad en la educacion superior, 8(2), 62-86. doi: http:// dx.doi.org/10.22458/caes.v8i2.1917

Sun, Z., Xie, K., \& Anderman, L. H. (2018). The role of self-regulated learning in students' success in flipped undergraduate math courses. The Internet and Higher Education, 36, 41-53. doi: https:// doi.org/10.1016/j.iheduc.2017.09.003

Teo, T., Lee, C. B., Chai, C. S., \& Wong, S. L. (2009). Assessing the intention to use technology among preservice teachers in Singapore and Malaysia: A multigroup invariance analysis of the Technology Acceptance Model (TAM). Computers \& Education, 53(3), 1000-1009. doi: https://doi. org/10.1016/j.compedu.2009.05.017

Tejada Fernandez, J. \& Pozos Perez, K. V. (2018). New scenarios and trainers' digital competencies: towards the professionalization of teaching with ICT. Profesorado, 22(1), 25-51.

Tikoria, J., \& Agariya, A. K. (2017). ICT enabled classroom effectiveness scale development and validation: A case of multi-campus university. Knowledge Management \& E-Learning, 9(1), 111-127. 